\title{
Archaeological Testing at Rancho de las Cabras, Wilson County, Texas, Third Season
}

Courtenay J. Jones

Anne A. Fox

Follow this and additional works at: https://scholarworks.sfasu.edu/ita

Part of the American Material Culture Commons, Archaeological Anthropology Commons, Environmental Studies Commons, Other American Studies Commons, Other Arts and Humanities Commons, Other History of Art, Architecture, and Archaeology Commons, and the United States History Commons

Tell us how this article helped you.

This Article is brought to you for free and open access by the Center for Regional Heritage Research at SFA ScholarWorks. It has been accepted for inclusion in Index of Texas Archaeology: Open Access Gray Literature from the Lone Star State by an authorized editor of SFA ScholarWorks. For more information, please contact cdsscholarworks@sfasu.edu. 


\section{Archaeological Testing at Rancho de las Cabras, Wilson County, Texas, Third}

Season

\section{Creative Commons License}

\section{(c) (1) (9)}

This work is licensed under a Creative Commons Attribution-NonCommercial 4.0 International License 


\section{Archaeological
Testing at}
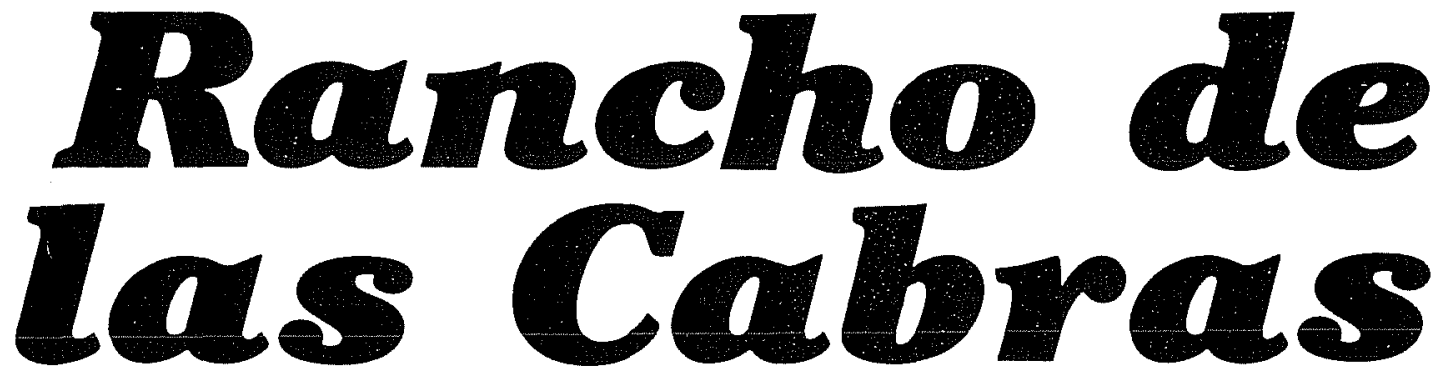

Wilson County,

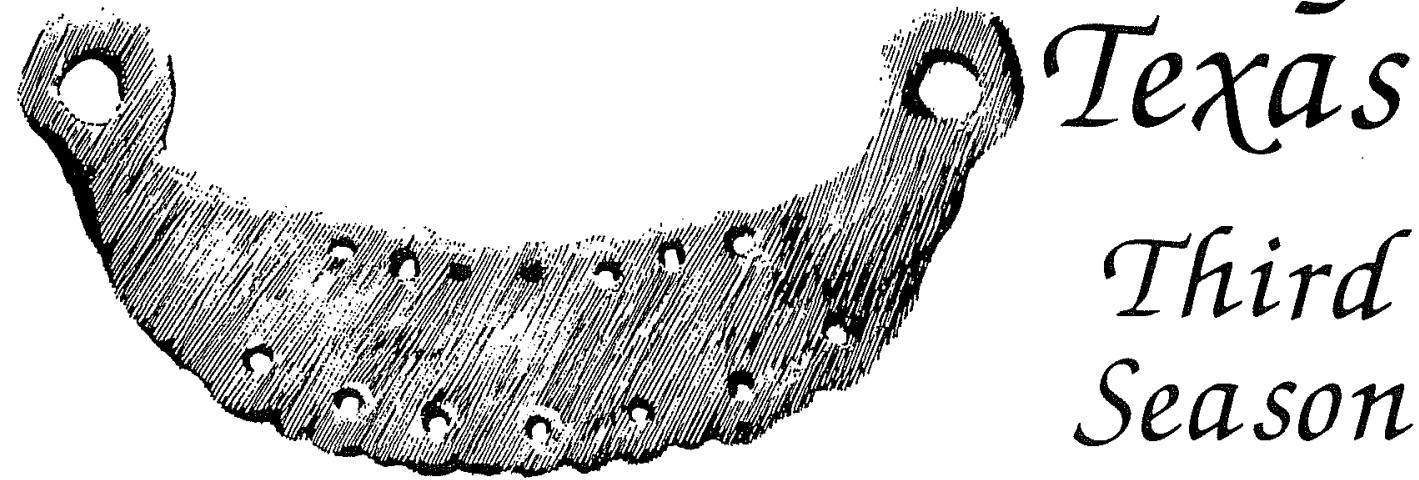

COURTENAY J. JONES

and ANNE A. FOX

Center for Archaeological Research

The University of Texas at San Antonio

Archaeological Survey Report, No. 123

1983 





\title{
ARCHAEOLOGICAL TESTING AT \\ RANCHO DE LAS CABRAS, WILSON COUNTY, TEXAS.
}

THIRD SEASON.

\author{
Courtenay J. Jones \\ and \\ Anne A. Fox
}

Center for Archaeological Research The University of Texas at San Antonio Archaeological Survey Report, No. 123 
The following information is provided in accordance with General Rules of Practice and Procedure Chapter 41.11 (Investigation Reports), Texas Antiquities Committee:

1. Type of investigation: Historical, architectural, and archaeological at the Rancho de las Cabras;

2. Project name: Rancho de las Cabras;

3. County: Wilson County, Texas;

4. Principal Investigators: Thomas R. Hester, Principal Investigator; Jack D. Eaton and Anne A. Fox, Co-Principal Investigators;

5. Name and location of sponsoring agency: Texas Parks and Wildlife Department, Austin, Texas;

6. Texas Antiquities Committee Permit No. 313;

7. Published by the Center for Archaeological Research, The University of Texas at San Antonio, San Antonio, Texas 78285, 1983. 


\section{ABSTRACT}

An analysis of the 1982 field season activities at Rancho de las Cabras (41 WN 30) is presented in this report. Additional data concerning structural details and construction activities at the site are presented. The results of further archival research provide additional information concerning the history of the Rancho de las Cabras site, its relationship to Mission Espada, and the adjacent landowners. An expanded genealogy is presented of the Calvillo and Delgado families, both intimately connected to Rancho de las Cabras. Recommendations are made for further work at the site. 


\section{TABLE OF CONTENTS}

ABSTRACT . . . . . . . . . . . . . . . . . . . . . . . . LIST OF FIGURES . . . . . . . . . . . . . . . . . . . . . . i . . . . .

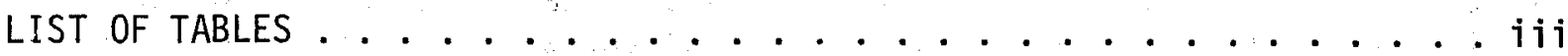

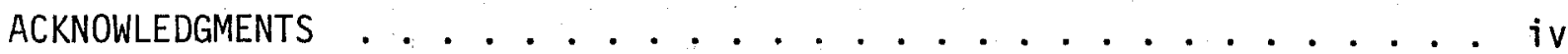
INTRODUCTION . . . . . . . . . . . . . . . . . . . . . 1 THE SITE ............................. 3 HISTORICAL BACKGROUND . . . . . . . . . . . . . . . . . . 1

The Mission Period . . . . . . . . . . . . . . . . 3 Rancho de las Cabras and Ygnacio Calvillo............ . 4 The María Calvillo Period . . . . . . . . . . . . . . . 6 Post-Calvillo to the Present Day ............... 11 The Delgado Family . . . . . . . . . . . . . . . . 12

The Calvillo Family . . . . . . . . . . . . . . . 13 THE EXCAVATIONS ...................... . . 15

Methodology ....................... 15

The Southwest Corner Units . . . . . . . . . . . . 18

The Chapel Area Units . . . . . . . . . . . . . . . . 23

The Test Pits...................... . . 33

CULTURAL REMAINS . . . . . . . . . . . . . . . . . . . . 34

Bone (William McClure) . . . . . . . . . . . . . . . 34

Ceramics ......................... 38

Glass........................ . . . 42

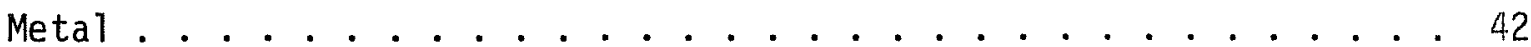

Stone......................... . . 42

Soil, Mortar, and Plaster ................ . . 43

Artifact Discussion... . . . . . . . . . . . . . . 42 


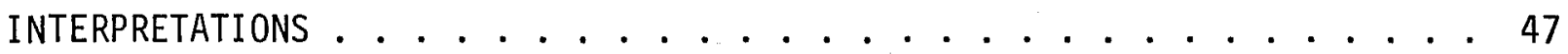

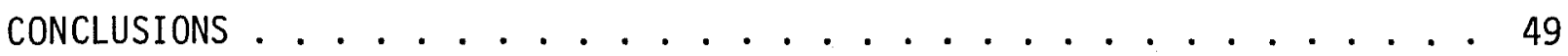

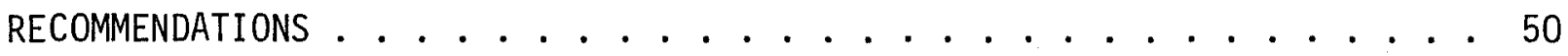

REFERENCES CITED ........................ 51

APPENDIX: PROVENIENCE OF FAUNAL MATERIAL (William MCClure) . . . . . 54

\section{LIST OF FIGURES}

1. Map Showing the Location of Rancho de las Cabras . . . . . . . . . 2

2. Map of the María Calvillo Grants ............... 8

3. Plan of Compound Showing Location of 1982 Excavations . . . . . . 16

4. Pertinent Surface Elevations ................ 17

5. Unit Profiles .................. 19

6. Views in the Southwest Corner ............... 22

7. Location of Features South of the Chapel . . . . . . . . . 25

8. Views in Front of the Chape1 . . . . . . . . . . . . 27

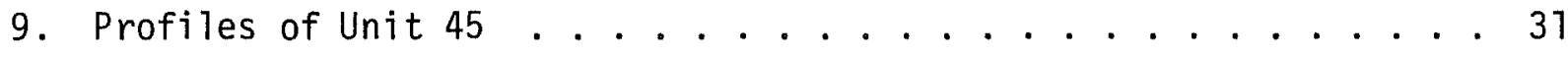

10. Selected Artifacts from 1982 Excavations . . . . . . . . . 41

11. Jacal in San Antonio, Mid-19th Century . . . . . . . . . . 48

\section{LIST OF TABLES}

1. Provenience of Cultural Remains from 1982 Season . . . . . . . . 45 


\section{ACKNOWLEDGMENTS}

Much of the credit for any project goes to individuals who often go unnoticed by the public. These individuals make significant contributions in time, labor, and especially knowledge. Through such contributions much groundwork and expense is avoided.

A grateful thank you, on behalf of the entire crew, go to Cecil Peel, Joan Sherwood, Rita Neureuther, Shirley Van der Veer, and Judy Barber, all of whom generously donated volunteer labor to the project. Thanks also to Bob and Joyce Ruthe, and their two children, Joyda and David, who were also volunteers.

Winston and Jo Ann Southern deserve a special thanks for their assistance with this project, during this season as well as previous seasons. As the previous owners of the Rancho de las Cabras site, they have demonstrated an ongoing interest in preserving the site. Thanks also to Ray Lambert, who is currently leasing the property surrounding the site. He was cooperative in providing access and also closed off the area to his cattle during our field work.

Winston Davis was instrumental in acting as a liaison for the crew and graciously forwarded messages to and from the crew. Crew comfort was elevated considerably through his loan of a refrigerator. Mr. Davis also served as liaison between the crew and the Wilson County Historical Commission. This commission expressed an active interest in our work and made available to us their knowledge concerning the history of Wilson County.

Thanks also to Roy Swift, Chairman of the Wilson County Historical Commission, who, on the behalf of the Commission members, extended an invitation to the crew members to attend their June meeting during our stay at the Rancho de las Cabras site.

A special thanks to John Leal, Bexar County Archivist. As on other projects, $\mathrm{Mr}$. Leal repeatedly made his resources available to CAR personnel during this project and generously shared his knowledge of the Colonial period in Texas. His earlier work in translating Spanish documents was most helpful to our research. 


\section{INTRODUCTION}

The 1982 field season at Rancho de las Cabras was the third of a scheduled four season project conducted by the Center for Archaeological Research, The University of Texas at San Antonio (CAR-UTSA). This project is sponsored by the Texas Parks and Wildlife Department, Austin, Texas, and is designed to provide both historical and structural information to be used by the Department in preserving the site of Rancho de las Cabras as a historical park. Future plans by the Parks and Wildlife Department include the construction of a visitor's center and opening the site to the public. Rancho de las Cabras (41 WN 30) is listed on the National Register of Historic Places and is a State Archeological Landmark. Investigations were carried out under Texas Antiquities Permit No. 313.

This season's field work was authorized by an interagency contract (82-83 \#1265) between the State of Texas and the CAR. The principal investigator was $\mathrm{Dr}$. Thomas R. Hester, Director of the CAR. The co-principal investigators were Jack D. Eaton, Associate Director of the CAR, and Anne A. Fox, Research Associate. Field activities were directed by Anne A. Fox.

The field crew consisted of the following CAR personnel: Lois Flynn, Katherine Gonzalez, Margaret Mehrtens, Dennis Knepper, Margaret Greco, and Courtenay Jones. Archival research was accomplished by I. Waynne Cox and Courtenay Jones.

William McClure conducted the analysis of the animal bone materials recovered during this season's field work. The artifact analysis was done by Anne Fox, and the illustrations and data charts were prepared by Kenneth Brown and Katherine Gonzalez of the CAR.

\section{THE SITE}

Rancho de las Cabras is located on a high point of land that overlooks the confluence of the Picosa Creek and the San Antonio River in WiTson County, Texas (Fig. 1). The site is approximately four kilometers southwest of Floresville and two kilometers west of the San Antonio River. This location affords a panoramic view of the San Antonio River valley to the east.

The site is located in the Dewees Quadrangle (Wilson County, Texas) of the USGS Series Topographic Maps. Using the 1961 edition of the USGS 7.5 Minute Series Maps, the UTM coordinates for the Rancho de las Cabras site are E (5) $78.14, N(32) 1860$.

The soil in the area of Rancho de las Cabras varies from tannish to medium reddish brown sandy loam that overlies a yellowish brown clayey soil. The vegetation in this area consists of live oak, post oak, and some pecan. Mesquite and thorny underbrush varieties are the dominant species in the immediate area of the site. Sparse, short grasses are also present. 
This page has been

redacted because it

contains restricted

information. 
The compound is an irregular-shaped, four-sided structure with at least three rooms attached to the inside of the north wal1. A fourth enclosure, the chapel, is located in the eastern portion of the compound. Traces of two earlier walls indicate that the compound underwent at least one, possibly more, major renovations. Among the renovations were the addition of two defensive bastions at the northwest and southeast corners of the compound. Additional details concerning the construction of the compound are provided by Ivey (1983).

\section{HISTORICAL BACKGROUND}

\section{The Mission Period}

After Mission Espada was moved from East Texas to $i$ ts present location in March 1731 (Habig 1968:202), the mission was granted an additional tract of land along with the land on which the mission was located. All of the Texas missions were given such grants in order to provide the necessary grazing land for herds of livestock and to provide acreage for growing crops. The lands of Mission Espada included the site of Rancho de las Cabras that was constructed to house the caretakers and workers who maintained the herds and crops. The walled compound was constructed to provide security for the workers against Indian raids, which occurred with increasing regularity through the latter half of the 18th century and into the 19th century. Habig $(1968: 202,204,210,211)$ records the increases in Mission Espada's animal inventories during the years 1740-1745. Ivey (1983) indicates that it was during these years that Mission Espada began to develop and achieve large scale ranching activities. Ivey's (ibid.) analysis of a 1772 inventory of Mission Espada's property and possessions, compiled when control of the Texas missions was transferred from the Queretaran missionaries to the College of Zacatecas, reveals the large scale on which ranching activities were conducted. Ivey (1983) also examines the relationship between the mission and its ranch, demonstrating the importance of the ranch supply system in providing for the inhabitants of the mission. Freedom from such tasks would have allowed the mission staff to concentrate on their primary purpose; that of educating and converting the Indian inhabitants.

Ivey's (ibid.) synopsis of the early years of the Mission Espada ranchlands includes a detailed account of the boundary descriptions of the lands and the associated litigation involved in acquiring title to these lands. Ivey (1983) also provides an insight into the legal battles fought between the missions and secular ranchers, both having vested interest in obtaining clearly defined titles. His analysis of a countersuit filed by Don Vicente Alvarez Travieso and Don Juan Andres Travieso in 1771, objecting to a request by Mission Espada for additional lands, typifies what was apparently a recurring issue.

Although the 1762 inventory of Mission Espada notes that the mission has ". . a good stone house where the cowboys and shepherds could live comfortably. . ." (Habig 1968:215), and the diary of Father Solis mentions passing through a "goat ranch" during his journey from Mission Rosario (Forrestal 1931: 18), the first time the term "Las Cabras" is used to identify the ranch of Mission Espada apparently appears in a document dated March 9, 1772. This 
document, written by Fr. Asiselos Valverde, mentions ". . . the Lands of the Rancho of Espada, named Las Cabras; . .." (BA microfilm roll 30 frame 36053606). Another document, dated January 8, 1787, defines the 1 imits within which Mission Espada is authorized to conduct its cattle operations. This latter reference mentions the ranch of Ygnacio Calvillo, which lay to the north (BA microfilm roll 18 frame 7 ). Ivey (1983) notes the mission ranch continued in operation through the "Great Round-up of 1787," serving as the headquarters for this operation. Shortly after this time, the mission lands began to be secularized, and lands once owned by the missions were being reallocated to private citizens. Although secularization of mission lands started in 1794, the lands of Mission Espada were still being parceled out as late as 1809 (ibid.).

Rancho de las Cabras and Ygnacio Calvillo

The available data suggests that secular ranching interests were encroaching upon the mission lands at least as early as the 1760s. In 1770, the Special Judge of Lands and Waters was charged with reviewing the various mission land holdings for the purpose of allocating unused portions to secular ranchers (Ivey 1983). A lease arrangement of sorts was accomplished by Ygnacio Calvillo for the use of some of the northern portions of the Mission Espada ranchlands. This arrangement is referred to in an 1809 petition by Ygnacio Calvillo requesting land (ibid.). This petition, however, was not the first to be filed by Calvillo.

Prior to 1778 Ygnacio Calvillo petitioned for two sitios of land in order to maintain his herds (GLO Spanish Archives Vol. 50:187). According to Ivey (1983), Calvillo again petitioned for ranchland on May 17, 1778. In this second petition he requested title to a piece of property known as "el paso de las Mujeres," located between the Rancho de las Cabras and the Rancho del Challopin. Although no evidence has surfaced to date which actually documents this request, it seems this petition was granted. Calvillo's ranch, El Paso de las Mujeres, is referred to in a document dated January 8,1787 , which defined the boundaries of the lands on which Mission Espada was authorized to conduct its cattle roundup (BA microfilm roll 18 frame 7). Calvi110's name also appears on a list of "officially recognized ranches and proprietors" (Chabot 1937:168). This document is dated November 8, 1791. As noted earlier, Calvillo filed yet another petition in 1809 for two sitios of 1and (BCA Mission Records 36FE). In this document Calvillo states that he had established the ranch (El Paso de las Mujeres) about 35 years ago and, although he had suffered the Indian hostilities and had paid as much as he could, he had lost some property due to nonpayment (ibid.). If Calvillo had indeed established the ranch 35 years prior to 1809 , it indicates that he initially started working the property ca. 1773-1774. This would place him in control of the property several years prior to his petitions of 1778 and earlier. With these facts in mind, a possible reconstruction of events is offered.

According to Calvil10's 1809 petition, he had occupied El Paso de las Mujeres ranchlands since 1773 or 1774 . By 1778 Calvillo may have felt justified in seeking title to the property, especially since Mission Espada had not used it for the four or five years it had been leased to him. This period may have 
been even longer. Since the mission had not used the land for a period of time, Calvillo's petition may have had some merit under the 1770 edict mentioned earlier. Assuming that $\mathrm{Ca}$ lvillo was granted these lands as a result of this request, the entire ranch of El Paso de las Mujeres would have lain to the north or northwest of Mission Espada's Las Cabras ranch. This seems to be indicated in the 1787 document which allowed Mission Espada to conduct its ranch operations as far north as the "Calvillo ranch" (BA microfilm roll 18 frame 7). This would also conform to Calvillo's 1778 petition in which he requests a tract of land between the "Rancho del Challopines" and the Rancho de las Cabras (Ivey 1983). This would also account for Calvillo being included in the 1791 1 ist of property owners. It should be noted that his name appears in the section that 1 ists those properties which are unimproved, probably indicating that Calvillo's occupation of the ranch was on an "as needed" basis, i.e., roundups, harvests, etc., rather than as a homesite.

Since Calvillo again petitions for title to El Paso de las Mujeres ranch in 1809, he may have lost title to some or all of it through default. He indicates such difficulties in his 1809 petition, and since the property was still unimproved as late as 1791 (no residence established?), Mission Espada may have petitioned for the return of the property on such grounds. In the documentation associated with the 1809 petition, Fray Pedro Noreña, of Mission Espada, states". . I declare that the said Calvillo occupies the aforementioned 'Paso de las Mujeres' which belongs to the ranch of this mission... (ibid.). The return of this property would have occurred between 1791 and 1809 . Since the secularization of mission lands started ca. 1794, it would seem 1 ikely that Mission Espada's action would have occurred in the earlier part of this period, and Calvillo's 1809 petition was a successful attempt to regain ownership of the property under the secularization edict.

Such actions between missions and secular ranchers were not uncommon. Ivey (1983) cites a similar case in which Mission San Antonio de Valero reacquires property it lost to two individuals under the 1770 edict. This petition, filed in 1778, resulted in the lands being returned to Mission San Antonio de Valero because the two individuals in question had not ". . . fulfilled the necessary terms of occupation for fult legal ownership."

Archival research has produced a 1770 petition by Ygnacio Calvillo for a suerte of land along San Pedro Creek (BCA Land Grant and Sales 116). This petition was filed in 1773 by Calvillo (BCA Land Grant and Sales 117). This suerte of land is the same tract which appears in his name on a "List of Individuals who have bought 1 and and water at San Juan Mission from the Provincial Deputation," dated February 10, 1824 (BCA Mission Records 15). This date is ten. years after his death, but, this property may have continued to be occupied by his heirs while the title remained in his name. Such an occurrence was not uncommon during this era. Ygnacio Calvillo's two married daughters 1 ived close by, and all three households are listed in censuses for the years 1790, 1795, and 1804 for the resjents of San Juan de Bexar (Ivey 1983). Rather than contradict the 17911 ist of ranches and proprietors, these censuses seem to indicate that Calvillo was either maintaining two residences, one at the ranch and one at San Juan, or that he was living at San Juan and operated the ranch on a periodic basis. Since the 1791 list describes his ranch as being without improvements, it would seem likely that the latter living arrangement 
was the case. It is evident that by 1809 , when Calvillo repetitioned the Spanish government for title to El Paso de las Mujeres, he was actually in residence at the ranch. This is inferred in his 1809 petition. He is listed in an 1811 census as a "Resident of Santa Cruz y Paso de las Mujeres," recorded on January 10, 1811 (BA microfilm roll 47 frame 0805). Calvillo was residing at the ranch on April 15, 1814, when he was killed during a raid on his ranch. During this raid, a chest belonging to Calvillo was stolen. Initially thought to have been an Indian attack, subsequent investigations revealed that one of the raiders was one of Calvillo's grandsons. Ivey (1983) includes excerpts from some of the proceedings in this case.

The foregoing interpretation differs somewhat from the interpretation presented by Ivey (ibid.). In his view, the lands, on which the site of Rancho de las Cabras is located, probably came into the possession of the Calvillo family as a result of Ygnacio Calvillo's 1809 grant. The reconstruction of events presented in this report is based, in part, on the research accomplished by Ivey and also on research material not available to him at the time of his report. This interpretation also relies on the accuracy of the translated documents. Such translations are not always precise. Both views should be considered as tentative and subject to revision as new data become available through future research. Ideally, such research would locate the petition by Mission Espada for the return of its lands, if such was the case.

A more definite history of the site of Rancho de las Cabras and the Calvillo family can be reconstructed from the time that Maria Calvillo, Ygnacio's daughter, assumes control and possession of the ranch.

The Maria Calvillo Period

Research to date has provided little information concerning the early years of the marriage between María del Carmen Calvillo and Gavino Delgado. They were married $\mathrm{Ca}$. 1781, based on the birth record of their first child, Juan Baustista (SFA Baptismal Records 1783 no. 1161). A second child, Jose Anacleto, was born in 1784 (Chabot 1937:172). Three other children were adopted by the couple, or at least by Maria Calvillo. These children were: Maria Concepcion Gortari, born 1803 (1811 Census of the Residence of Santa Cruz y Paso de las Mujeres, BA microfilm roll 47 frame 0805); Juan Jose, a mestizo (halfbreed), born 1793 (based on SFA Marriage Records 1811 no. 108), and Antonio Duran (Maria Calvillo's will). Of these five children, only Antonio Duran and Maria Gortari are mentioned in the will of Maria Calvillo, implying that the other three children had died before Maria.

According to available evidence, Maria Calvillo was living in the vicinity of Mission San Juan. She appears in the 1790, 1795, and 1804 San Juan Censuses (Ivey 1983). She was apparently living there in 1810. She was given title to a suerte of land at Mission San Juan in 1823. In her petition she states that she had been a resident of the mission for the past thirteen years (BCA Mission Records 6, dated December 27, 1823). She appears on the 1824 "List of Individuals who Owned Property at San Juan" (BCA Mission Records 15). Ivey (1983) suggests Gavino Delgado may have also been living at Mission San Juan during this period. Shortly after this time Maria and Gavino separated, perhaps due to Gavino's political activities (ibid.). This view is probably, 
based, at least in part, on a statement made in 1814 in which María states that she left her husband when the soldiers of the King entered the city of San Fernando de Bexar (BA microfilm roll 53 frame 686; see also The Delgado Family section of this report). According to the 1811 census, they were both 1 iving at the Calvillo ranch in 1811. Ivey (1983) notes that Maria and her physician were temporarily living at the Calvillo ranch in 1814 at the time of her father's death.

Apparently sometime between 1814 and 1823 María moved back to Mission San Juan to her residence that she evidently maintained even during her absence. This move was probably shortly after her father's death. In 1823, Maria states that ". . . her husband . . . died trying to defend the present Government System" (Ivey 1983). This statement may be associated with her 1823 petition for the suerte of land at Mission San Juan, but it seems to conflict with the official record. According to the Camposanto Burial Records maintained by the San Fernando Church (now, San Fernando Cathedra1), Gavino Delgado died on April 24, 1825, ". . . at age 65 of a pain" (SFA Camposanto Burial Records 1825 no. 1252).

On August 28, 1828, María Calvillo petitioned the Mexican government for a new title to her father's ranch (BCDR Vol. 2:375). In this document she states that:
- . for many years she has populated a certain land, that she is ignorant of the number of leagues of which it is composed because the deeds which she had to it by her deceased father together with the chest were taken from her during the time of the Spanish Government. And knowing that the Citizen Francisco Flores has presented himself praying for the lands contiguous to the lands spoken of, which she at this time possesses, prays of you that you harken to her petition and in justice adjudge her in legitimate possession of two sitios of land as the original founder in accordance with the regulations of the colonization law, beginning at the place called the womans [sic] crossing... [Paso de las Mujeres].

The survey for this grant was accomplished on September 29, 1829. The survey was initiated on the west bank of the San Antonio River "between the ancient Goat Mission and the ruined sheep ranch..." (BCDR Vol. 2:375). The metes and bounds of the survey place the site of Rancho de las Cabras in the southern portion of this grant, firmly establishing Maria Calvillo as the owner of the Rancho de las Cabras site (Fig. 2). Evidently not all of the lands associated with the old Rancho de las Cabras were granted to Maria Calvillo. On August 12, 1830, Manuel Barrera petitioned for, and received, a parcel of land immediately southeast of the Calvillo grant (BCDR Vol. $11: 301$ ). In this petition, Barrera requests title to a tract of 1 and, currently in his possession, called ". . . E1 Rancho De Las Cabras Viejas . . . [the old Goat Ranch]." This reference must refer to a portion of what was once the ranchlands of Mission Espada, rather than the ranch compound itself. This reference may be associated with the fact that Maria Calvillo's southern boundary started between the "Goat Mission and the ruined sheep ranch," indicating that the portion requested by 


\section{THE MARIA CALVILLO GR ANTS}

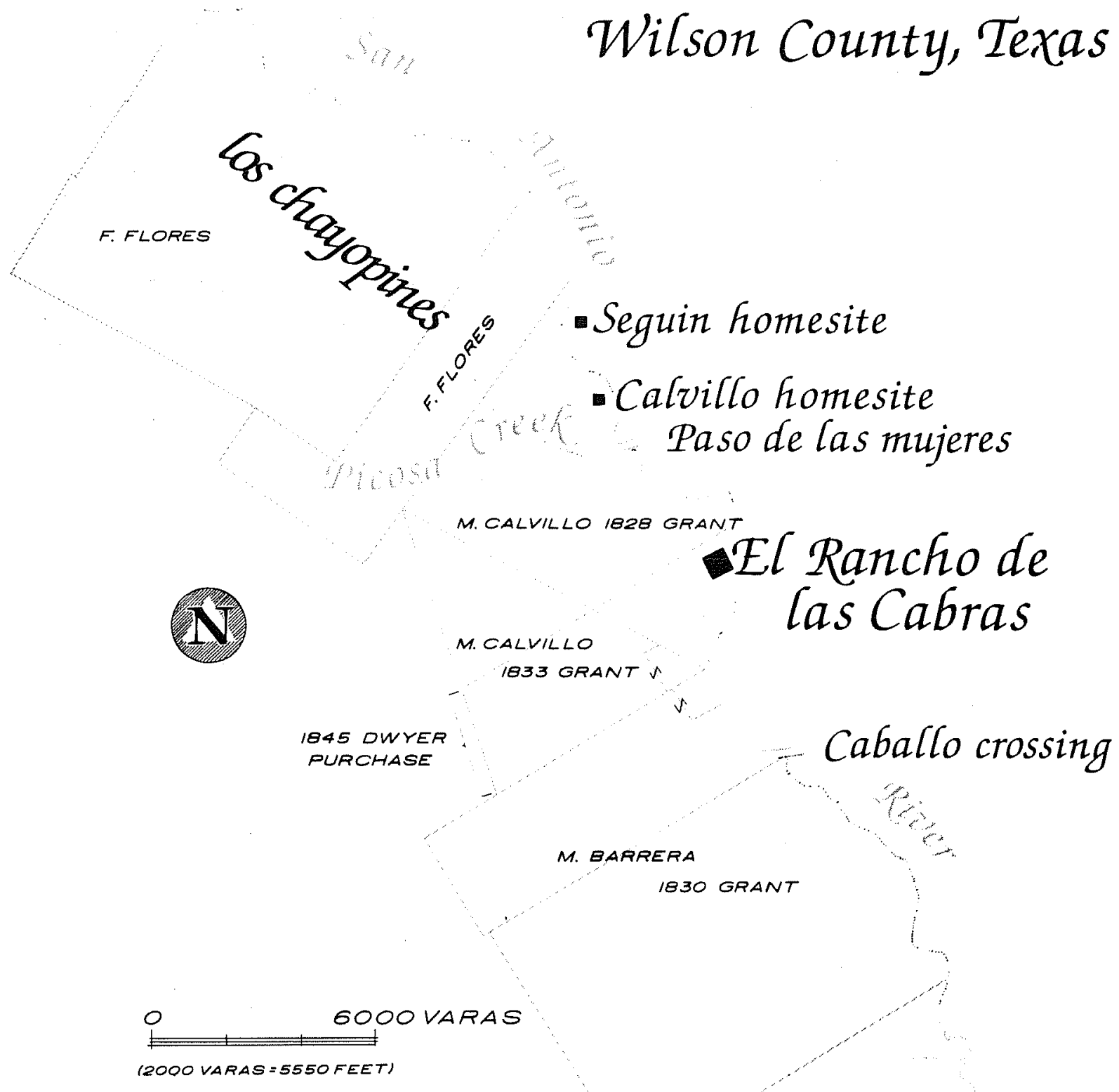

ADAPTED FROM 1921 WILSON COUNTY GENERAL LAND OFFICE MAP

Figure 2. Map of the Maria Calvillo Grants. 
Barrera was more likely the area known as the sheep ranch, but still at one time a part of the Mission Espada ranch.

Details of the early years of Maria Calvillo's ownership of Rancho de las Cabras are sketchy, but the circumstances which existed at the time may account for this void. Maria was 58 years old when she obtained title to her solar in Mission San Juan in 1823. She was 63 years old when she petitioned for the land grant in 1828 and 65 years old when Manuel Barrera requested his grant. In Barrera's grant he refers to the Indian raids which caused him to abandon the ranch. He also notes the considerable cost he incurred in replacing livestock which were lost in the ". . . continual war waged on this Department by the savage Indians, for which reason he lost everything and abandoned the ranch" (BCDR Vol. J1:301). Maria Calvil10's age and the threat of Indian raids may have prevented her from establishing an active fult-scale ranch operation.

Further evidence of Maria Calvillo's difficulties in operating the ranch as a going concern is indicated in a second petition filed by her on June 26 , 1833. In this petition she requests, and is granted, title to a third league of land immediately to the south of her first grant, between it and the Barrera grant. In this petition she refers to the:

- . deterioration of her landed property caused by the hostile wars of the enemy tribes; they having taken her father's 1 ife at the place where she has her present ranch, that her husband also died trying to defend the present Government System, that she has given whatever aid she could to help in the war against the Indians, and last- at her own expense, she put a man mounted and armed for the expedition which left under the command of Captain Don Manuel Lafuente, . . (GLO Spanish Archives Vol. $31: 75$ ).

This second grant, consisting of one league and a labor, placed Maria Calvillo in possession of three leagues of land, including the site of Rancho de las Cabras. It should be noted that this analysis of the difficulties which Maria Calvillo faced is contrary to popular legend. Legendary accounts of Maria describe her as an accomplished horsewoman who was often seen riding across the ranchlands on her white horse "with her long, dark hair flowing in the breeze." Legend also maintains that Maria had established a certain rapport with the Indians, providing them with beeves on occasion. No documentation has yet surfaced which would substantiate either of these claims.

During the years 1844 to 1851 Maria Calvillo sold or gave away as gifts several parcels of land from the Calvillo grant. These transactions include:

Date

Sept. 3, 1844

Jan. 25, 1845

Jan. ? , 1845
Transaction

Calvillo sale to Small

Final deed to Smal1

Calvillo sale to Edward Dwyer
Bexar County

Deed Records

Vol. B2:316

Vol. C2:25

Vol. C2:42 
Date

June 19,1845

Dec. 23, 1848

Oct. 14,1850

June 1 or 2, 1851
Transaction

Calvillo sale to Muñoz

Calvillo gift to Muñoz

Calvillo gift to Margarita de la Garza de Diaz

Calvillo sale to Matias Diaz
Bexar County

Deed Records

Vo1. C2:133

Vol. $\mathrm{H1}: 142$

Vol. $\mathrm{J1}: 20$

Vol. $\mathrm{K} 1: 60$

On the 10th of August, 1851, María Calvillo filed a restatement of her will (BCDR Vol. J1:68). This document replaced the original will which was made in 1845 and subsequently lost. In this will Maria assigns all of her property, both real and personal, to her "regular heirs that have been with her since infancy--Maria Concepcion Gortari and Antonio Duran" (ibid.). In this document she names Dr. Lucas Muñoz as the guardian of Duran, a minor. At this point the legal record provides a fascinating insight into the personal life of María Calvillo.

The day after Maria restates her will and assigns all of her possessions to her two surviving adopted children, she deeds all her property along the San Antonio River to Matias Diaz in exchange for his care of her for the rest of her life (BCDR Vol. K1:82, August 11, 1851). As noted earlier, Diaz bought land from Calvillo before and is probably related to the Margarita Diaz (husband and wife?) to whom María Calvillo gave a gift of land.

Just two weeks after this event, Dr. Lucas Muñoz filed a petition in the Bexar County Probate Court requesting the court to declare Maria Calvillo non compas mentis, due to extreme old age (BCPCR 1851:August Session). This petition was initially granted and allowed Muñoz to sell Calvillo's property in the interest of Duran, with the consent of Maria Gortari. These transactions included:

\section{Date}

May 2, 1852

Feb. 7, 1854
Transaction

Muñoz sale to Guilbeau

Muñoz sale to Edward Dwyer
Bexar County

Deed Records

Vol. $\mathrm{K1}: 639$

Vol. L2:249

When María Calvillo died on January 15, 1856 (SFA Burial Records 1856 no. 1227), Inez Saucedo de Garza entered the picture. Claiming to be the only blood relative of Maria Calvillo, de Garza petitioned the court to be declared the legal heir to the Calvillo estate. Inez Saucedo de Garza stated that no will existed (BCPCR Minutes Book C:542). This action seems to be connected to an earlier agreement between de Garza and Roderick Higgenbotham in which de Garza agrees to sell all claims to the Calvillo estate to Higgenbotham for $\$ 1000$ (BCDR Vol. K1:327, Nov. 28, 1851). Although this action was initially approved, subsequent legal actions brought by Muñoz continued, and on April 4, 1857, Muñoz was reinstated as the legal guardian for Duran and as the executor of the estate. In this action Duran and Gortari were again declared the legal heirs (BCPCR 1857 Minutes Book:56). 
Following this action, Muñoz renounced his role as executor, and Antonio Duran was named as executor of the Calvillo estate (ibid.). The Bexar County Deed Records list the following transactions concerning the Calvillo estate, including the San Juan property:

Date

Aug. 7,1856

Nov. 28,1857

Dec. 29, 1857

March 12, 1859

March 12, 1859

March 12, 1859

March 12, 1859
Transaction

Paschal purchase by default Margarita de Garza de Diaz sale to Higgenbotham

Duran and Gortari sale to Herrera

Duran, Nicolas de la Cruz, and wife, Gortari sale to Herrera

Duran, de la Cruz, and Gortari sale to Supervide

Duran quitclaim to Gortari

Duran sale to de la Cruz and Gortari
Bexar County Deed Records

Vol. P1:580

Vo1. $\mathrm{KI}: 325$

Vo1. P1:578

Vo1. R1:318

Vol. S2:369

Vo1. S1:134

Vo1. $51: 133$

Apparently Inez Saucedo de Garza continued legal action in her claim to the estate of Maria Calvillo. On 0ctober 16, 1858, a jury decision in this matter upheld the will of Maria Calvillo, naming Duran and Gortari as the legal heirs. Inez Saucedo de Garza was ordered to pay all court costs in the matter (BCPCR Case \#1877, Minutes Book E:248). On June 13, 1860, a final sale involving the heirs of María Calvillo was recorded in the Bexar County Deed Records. This transaction was a sale of 114 acres of land by Duran to Gortari (BCDR Vol. $\mathrm{H} 2: 544)$. Transactions concerning the site of Rancho de las Cabras after 1860 were filed in the records of Wilson County, formed in 1860.

Post-Calvillo to the Present Day

A records search of the Wilson County Deed Records provides a history of the ownership of the Rancho de las Cabras site from María Calvillo to the present day.

In January 1845, Maria Calvillo sold a portion of her grant to Edward Dwyer (BCDR Vo1. C2:42). This tract included the site of the Rancho de las Cabras compound. The deed for this transaction states that the tract being sold ". . includes the 01d Rancho, called the Rancho de las Cabras" (ibid.). Upon the death of Edward Dwyer, the property passed into the hands of his son, J. E. (Joseph) Dwyer. The following transactions, on file at the Wilson County Courthouse, trace the ownership of the Rancho de las Cabras site to the present:

Date

March 31, 1874

Aug. 8, 1882
Transaction

Dwyer sale to J. F. Camp

J. F. Camp sale to J. M. McCoy and J. R. Murray
Wilson County Deed Records

Vo1. C:296

Vol. $K: 250$ 
Date

Jan. 1, 1884

March 2, 1886

June 9,1904

Nov. 30,1905

oct. 17, 1906

Nov. 5,1910

March 20, 1913

Apri1 6, 1926

Jan. 29, 1935

Sept. 24, 1940

Dec. 10, 1942

Sept. 22, 1970
Transaction

J. R. Murray sale of partnership to J. M. McCoy

J. M. McCoy sale to J. F. Camp

Mrs. L. W. Camp (daughter-in-law to J. F. Camp) sale to Houston, Green, and Tom

Green, Houston, and Wechausen sale to 0 . P. Rushing

Wife of O.P. Rushing sale to Otto Albert

Green, Houston sale to Eilert Kuck (this transaction refers to sale by Albert to Green et al.)

Eilert Kuck sale to Dietrich Ohl enbusch

Anna Ohlenbusch (wife of Dietrich) sale to $C$. B. Stevenson

Stevenson sale to Mrs. Charlie Matlock

Charlie Stevenson Matlock (relationship to Mrs. Charlie Matlock is not clear, probably son) sale to H. M. Lynn

H. M. Lynn and wife sale to Victor George

Viola George Shives (daughter of Victor) sale to Winston and Jo Ann Southern
Wilson County

Deed Records

Vol. $N: 7$

Vo1. $P: 80$

Vo1. $51: 574$

Vo1. $49: 578$

Vol. $53: 257$

Vo1. $68: 210$

Vol. $81: 426$

Vol. 139:361

Vo1. $183: 251$

Vol. $204: 251$

Vo1. $212: 519$

Vo1. $432: 17$

The Rancho de las Cabras site remained in the hands of Winston and Jo Ann Southern until it was acquired by the State of Texas. Action to acquire the site was initiated by the State on May 4, 1977, and the acquisition was finalized on May 22, 1982 (218th Judicial District Court Records, Wilson County, Texas, Case no. 9474). The property is currently owned by the State of Texas and is being administered by the Texas Parks and Wildlife Department.

\section{The Delgado Family}

Maria Melano and Louis Delgado were among the group who left the Canary Islands in 1730 to found a civilian settlement at San Antonio de Bexar (Chabot 1937: 171; Cox 1902:146). Louis died enroute, according to Chabot (1937:171), and his wife (born ca. 1700 in Lancerote, Canary Islands) continued on to San Antonio, where she died in 1740 . Their son, Francisco, at one time served as a member of the cabildo, the governing body of the town (Cox 1902:155). He married Catarina de los Santos, and their son, Juan Gavin (Gavino) de Trinidad Delgado, was born on October 17, 1758 (SFA Baptismal Records 1758 no. 443). 
Gavino Delgado's mother, Catarina de Tos Santos, was born in 1718 (Chabot 1937:160). According to the de los Santos genealogy published by Chabot (1937: 160), Catarina was the daughter of Antonio Santos, born in 1680 in Lancerote, Canary Islands, and Isabella Rodriguez, both of whom were among the Canary Island settlers. Catarina's paternal grandparents are listed as Simón Santos and Anna Rodríguez (ibid.).

Gavino Delgado was a prominent figure in the early years of San Antonio. He is mentioned in a list of individuals who applied for permission "to proceed to the other side of the Guadalupe River for cattle to supply meat for their families" (Chabot 1937:169). Gavino Delgado is also mentioned in the 1796 San Fernando Baptismal Records as having rescued an infant girl from the Apaches (SFA Baptismal Records 1796 no. 269). Although little is known concerning his marriage to Maria Calvillo and his personal life, his political activities during the 1811 and 1814 revolutions in Texas are better documented. As an "aristocrat from the Canary Islands," Delgado played an active role in the revolution of 1811 in which Casas overthrew the Spanish government. His activities during this time are recorded by Garrett (1939:42).

Concerned by the excessive authority displayed by Casas, and his mistreatment of fellow revolutionists, citizens under the leadership of Father Zambrano organized to mount a counterrevolution to unseat Casas. Delgado was one of 11 prominent citizens of the area who were praised for their efforts in a Royalist proclamation dated October 13, 1811 (BA microfilm roll 49 frame 0300). Garrett notes that Delgado was the victim of an ironic set of circumstances when he received this recognition. As one of Zambrano's followers, Delgado was expected to swear an oath to the Spanish king. It seems that Delgado was not expecting this counterrevolution to take such a direction. Garrett (1939: 50,73 ) provides an account of Delgado's activities during this time, and also notes that Delgado was quick to recognize his dilemma if he did not side with Zambrano.

Apparently Delgado's antiroyalist feelings persisted until the GuiterrezMcGee Revolution of 1813, when once again they surfaced. Not much is known concerning Delgado's specific activities during this time, however, in an official letter dated March 8, 1814, he appears on a list of "undesirables" (rebels) who are still alive and living in Bexar (BA microfilm roll 53 frame 0547). With the exception of his death on April 23, 1825 (SFA Burial Records 1825 no. 1252, age 65), no other data concerning the later years of Delgado's 1 ife has yet been found.

The Calvillo Family

Ygnacio Calvillo married Antonia de Arocha on November 26, 1760 (SFA Marriage Records 1760 no. 134). This is, thus far, the earliest record of Calvillo's presence in Texas. The San Fernando de Bexar census of 1795 identifies him as being Spanish and having been born in San Fernando, Spain (BA microfilm roll 26 frame 114). San Fernando de Bexar census reports for the years 1790, 1795, and 1804 list him as being 59, 50, and 62 years of age, respectively, while an 1811 census record of the "Residence of Santa Cruz y paso de las Mujeres" records his age as 77 . According to these sources, his birth date was between 1731 and 1745. Research to date has been unable to 
narrow this gap. His marriage record identifies him as the son of Jose Calvillo and Luzgarda Lopez de Lara. No additional information concerning his family is available at this writing, but it is possible that Calvillo's father may have been a member of the Presidial Company of Bexar, or perhaps a settler who preceded the arrival of the Canary Islanders in 1731 (Ivey 1983). The name Calvillo appears on a list written in 1745 that records those who should be considered the "first settlers" of the area (Cox 1902:148). For an unspecified period of time, Don Ygnacio Calvillo served in an official capacity as Procurador General of the Villa (Chabot 1937:71).

Antonia de Arocha, wife of Ygnacio Calvillo and mother of María Calvillo, was born in 1746, according to the 1811 census of San Fernando de Bexar. The 1795 San Fernando de Bexar census records her year of birth as 1750. She was the daughter of Francisco de Arocha, born in the Canary Islands in 1703 (Deuvall and Rodriguez 1975:attached chart; Chabot 1937:167) and Juana Curbelo, born 1716, in the Canary Islands (ibid.). Antonia de Arocha's maternal grandparents are recorded by Deuval1 and Rodriguez (1975:attached chart; see also Chabot 1937:167) as Juan Curbelo (born 1680, Canary Islands) and Garcia Prudhomme y Umpierre (born 1684, Canary Islands). Francisco de Arocha is listed as the Notary in 1735 (Cox 1902:157).

The San Fernando Burial Records 1 ist the death of Antonia Calvillo on September 21, 1819 (SFA Burial Records 1819 no. 963). Ygnacio Calvillo is listed in the 1815 SFA Burial Records (no. 672), however, according to the Bexar County Archives (BCA microfilm roll 53 frame 686) Calvillo was murdered on April 15, 1814, during a raid on his ranch by a group of attackers. This group was initially identified as Indians, but subsequent investigation revealed that Ygnacio's own grandson was among the group. Ivey (1983) provides a more detailed account of the official inquiry which was conducted following this incident.

Among the six children born to Ygnacio and Antonia Calvillo was Maria del Carmen, born July 9, 1765 (SFA Birth Records 1765 no. 145; Chabot 1937:168). Maria del Carmen is perhaps the best known of the children, and it was into her hands that the control and ultimate ownership of the Rancho de las Cabras lands passed. She was married to Juan Gavino de Trinidad Delgado ca. 1781. This date is based on the birth of their first child, Juan Baustista, born June 24, 1783 (SFA Birth Records 1783 no. 1161). Their marriage is also recorded by Chabot (1937:168). In addition to a second child born to this marriage, Maria Calvillo and Gavino Delgado adopted three other children. of the five children, only two of the adopted children, Maria Concepcion Gortari and Antonio Duran, were mentioned in the will of María Calvillo. Gortari and Duran subsequently inherited the Rancho de las Cabras property and are discussed in The María Calvillo Period section of this report. 


\section{THE EXCAVATIONS}

Field excavations for the third season at Rancho de las Cabras were conducted during the period June 2 through June 28, 1982. The purpose of the 1982 season was twofold: to continue testing within the compound for further evidence of construction and occupation activity and to test thoroughly the area adjacent to the chapel for evidence of possible burials. Twenty excavation units (Units 27-46) were opened during this season. These units were concentrated in two areas: immediately east and south of the chapel and in the southwest corner of the compound (Fig. 3). During the 1980 season a posthole was located in the southwest corner area in Unit 7 (Ivey and Fox 1981:19). Based on this evidence and the structural characteristics exposed in Area A during the 1981 season, it was decided that testing of the southwest corner of the compound might expose structural outlines of jacales located along either the south or west walls of the compound. In addition, this area was also selected in an effort to expose any additional structural evidence, if any, associated with the posthole in Unit 7.

Two test pits were also dug during this season (Fig. 3). One was located outside the compound walls, well away from the compound, and the second was located in the west central portion of the compound away from any of this season's units. These pits were excavated in order to examine the stratigraphic characteristics of the soil both inside and outside of the compound.

Methodology

Most of the units excavated this season measured $1 \mathrm{~m}^{2}$ or $1 \times 2 \mathrm{~m}$. However, when deemed necessary, units of nonstandard proportions were excavated. These units are so noted in the discussion of the units. A11 linear and vertical measurements were made using the metric system. When necessary, the English equivalent is given. Units were numbered sequentially in the order in which they were established. The first unit for this year was Unit 27.

Elevation data was based on the primary datum established for the site during the 1980 season. An arbitrary elevation value of $100.00 \mathrm{~m}$ was established for the primary datum. Beginning elevations for the units in the southwest corner were recorded with a transit and stadia rod. These elevations are presented in Figure 4 . All vertical measurements of the strata in these units were also taken from transit readings.

Vegetation and other obstacles made it impractical to use the transit for recording elevations in the chapel area units. A series of unit data was established for these units, and elevation information was recorded with a line level and string. The elevations for these data were recorded with a transit and are presented in Figure 4.

A basic series of five readily identifiable strata was developed from the 1980 and 1981 season notes. It was possible to apply this series on a site-wide basis as an aid in controlling this season's excavations. Some variation in this basic design occurred and are noted. The discussions of the units are based on these five basic strata. In some instances, more than one soil layer was recognized in a stratum. 


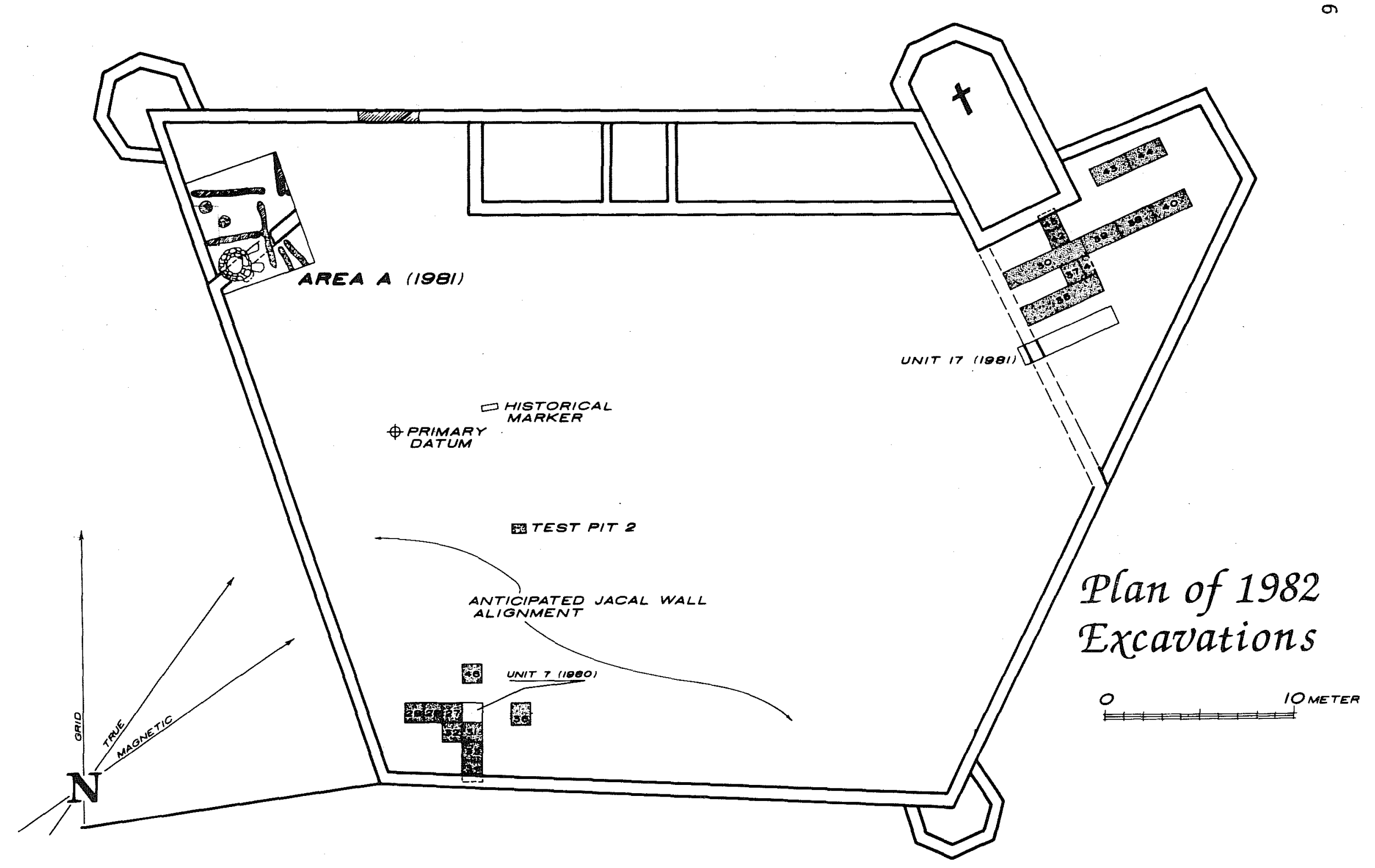

Figure 3. Plan of Compound Showing Location of 1982 Excavations. 


\section{Surface Elevations}
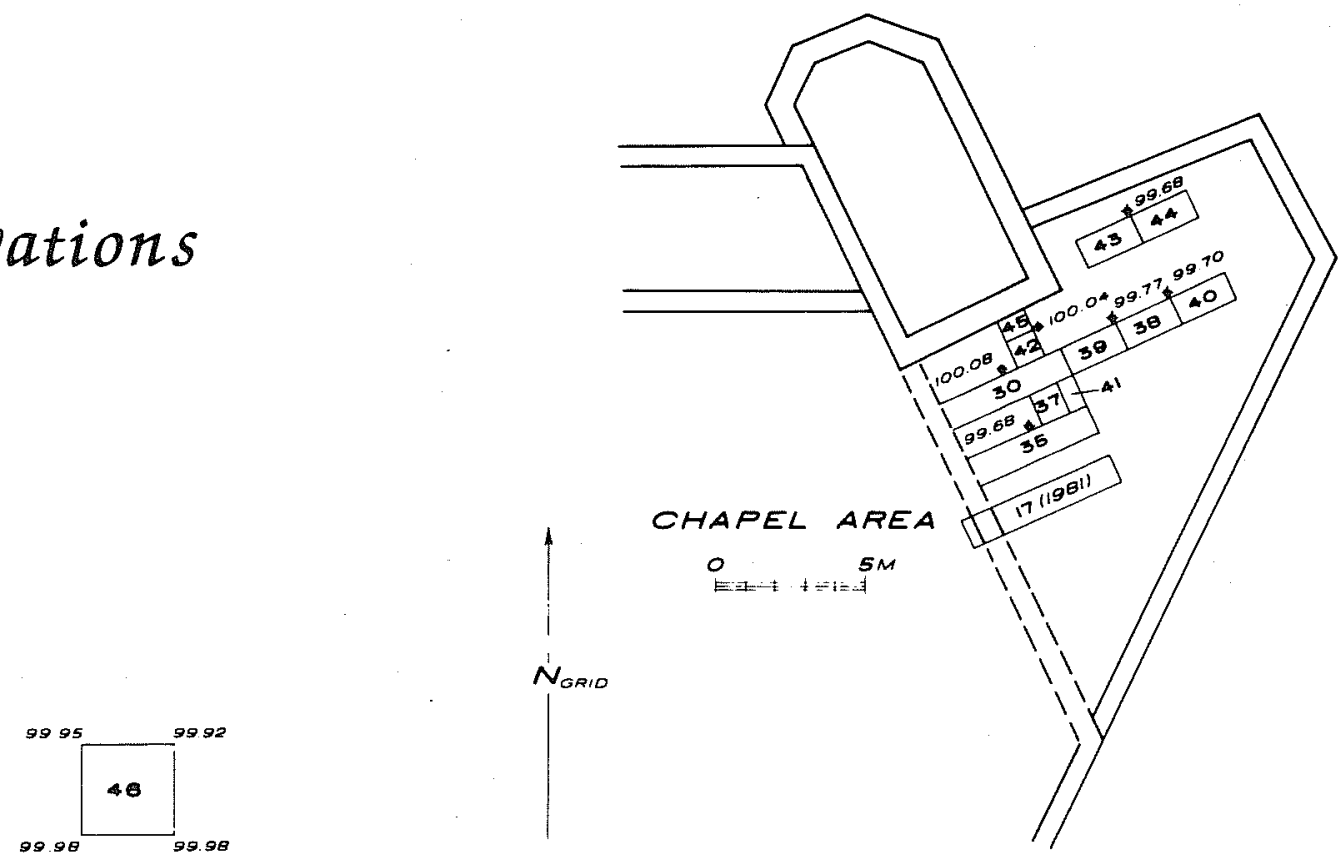

0

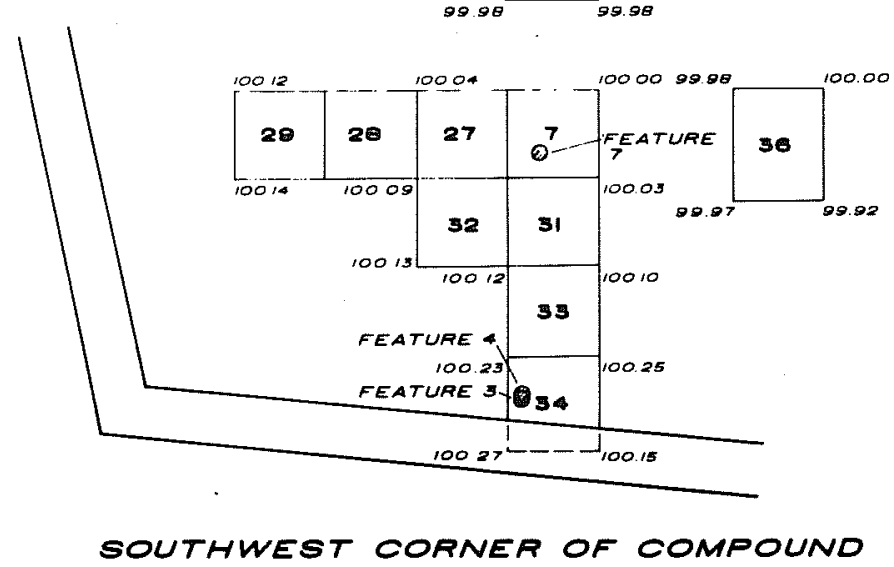

0 $5 M$ 
A11 units were excavated by layer, and individual unit/layer records were completed for each layer. These records are part of the project files and are on file at the CAR-UTSA. Each layer was assigned a lot number and coded. These numbers and codes were used to provide control measures for the materials as they were processed and analyzed in the laboratory. All recorded materials recovered from this season are stored at the CAR facilities.

All of the soil matrix excavated during this season's work was removed by hand, using trowels or shovels. Layers removed with trowels were screened through 1/4-inch hardware mesh screens and the recovered materials bagged. Layers removed with shovels were peeled off in thin layers and visually examined for cultural materials.

\section{The Southwest Corner Units}

Units 27,28 , and 29

These three units were aligned with Unit 7 (1980) and extended to the west of Unit 7 (see Fig. 3). Each of these units was $1 \mathrm{~m}^{2}$ and was excavated to a depth of approximately $35 \mathrm{~cm}$. Five distinct strata were identified in these units (see Fig. 5).

Stratum 1 consisted of a 4-6 cm layer of 1ightly compacted, tan-colored silty loam with minor root disturbance. Stratum 2 was a $6-10 \mathrm{~cm}$ layer of a grayish tan compacted loam containing a few small chunks of manure. Stratum 3 was a 7-9 cm layer of chunky manure, essentially void of any cultural materials. Within the upper three strata of Units 27 and 28 , bone fragments and chert were recovered.

Stratum 4 in these units consisted of a dark brown black loose silty loam, 4-7 cm thick, interspersed with ash residue and charcoal flecks. Stratum 4 in Units 27 and 28 were removed as one unit. Cultural materials recovered from these units at this level included bone, chert, and fragments of freshwater mussel she11. Goliad ware and lead-glazed pottery were recovered from this stratum in Units 27 and 28 . The Cultural Remains section of this report contains a detailed description of a soil sample taken from this stratum.

Stratum 5 consisted of five thin layers of a grayish brown surface, each of which was hard packed. This stratum was 5-8 cm thick. Materials recovered from all three units at this level included lead-glazed and Goliad ware, bone, and chert. Freshwater mussel shell and other unidentifiable shell fragments were also recovered from this stratum. One iron fragment, tentatively identified as a chain link (Fig. 10,g), was recovered from Layer 5 in Units 27 and 28. No structural evidence was noted.

observations: A large irregular-shaped charcoal and ash stain was noted on the floor of Stratum 4. This stain extended across the southern portions of Units 27 and 28 . In Unit 27, two irregular depressions, one $35 \mathrm{~cm}$ in diameter, the other $25 \mathrm{~cm}$ in diameter, were noted. The smaller depression was located at the northern edge of the charcoal/ash stain, and the larger depression was located at the eastern edge. These depressions extended into Stratum 5, varying in depth from 2-4 cm. As yet, no explanation can be given. 


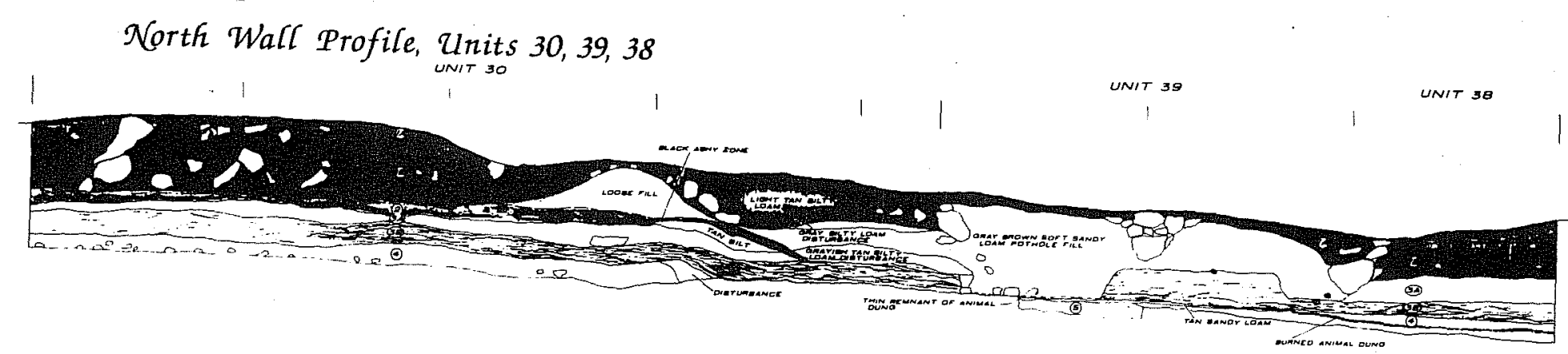

South Wall Profile, Unit 17

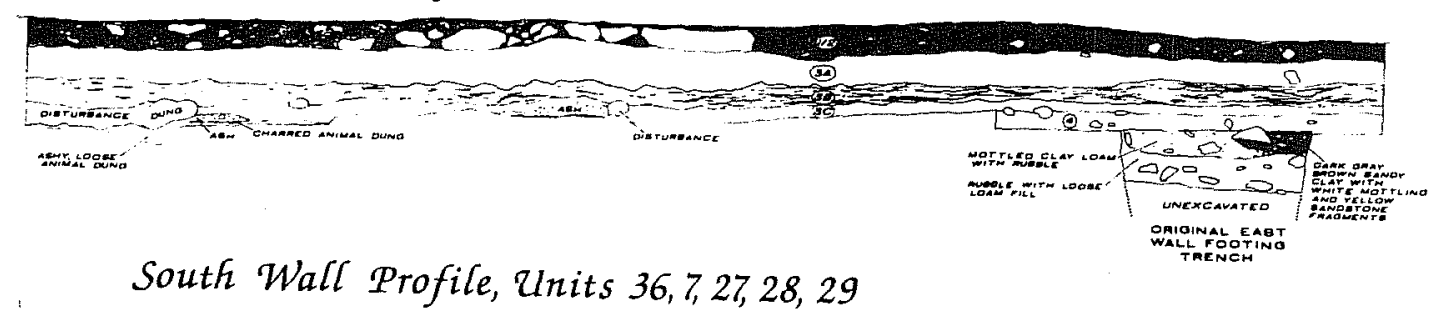

$\therefore$ roor

inandestone rpacancut

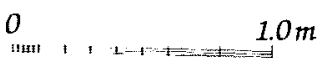

unit $=6$. Whall Profile, Znits $36,7,27,28,29$

UNIT 7

UNIT $27 \quad$ UNIT 28

UnIT 29
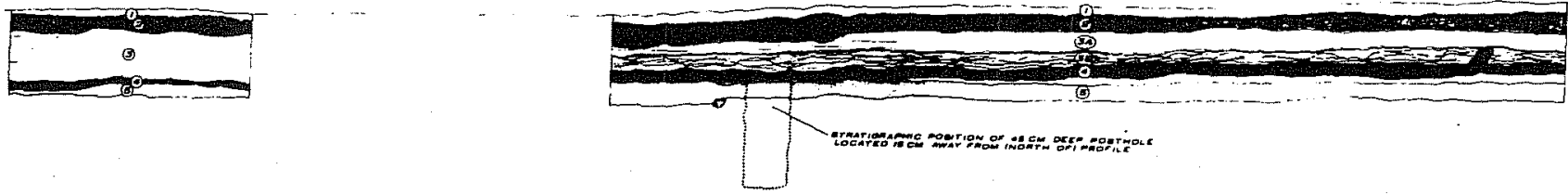

Figure 5. Unit Profiles. 
Units 31 and 32

Units 31 and 32 were also $1-\mathrm{m}^{2}$ units and were placed to the south of Units 7 and 27 , respectively. Five distinct strata were also recognized in these units. Stratum 1 consisted of a loose, tan-colored loamy soil, varying in thickness from $4-10 \mathrm{~cm}$. Minor rootlet disturbance was noted in this stratum, as were occasional tree root intrusions. Bone fragments were present in this stratum in Unit 31. Below this stratum, a layer of gray tan compacted loam was identified as Stratum 2. This stratum was a fairly consistent $7 \mathrm{~cm}$ in thickness in Unit 32 and varied from $4-10 \mathrm{~cm}$ thick in Unit 31. As in Stratum 1, bone fragments were also present in Unit 31. Stratum 3 consisted of a manure layer 6-8 cm thick. Bone was present in this layer in Unit 31 , but not recorded in Unit 32 .

Conforming to the other units in the area, Stratum 4 in these two units consisted of a dark brown black silty loam. Charcoal and ash residue were present in this stratum. Cultural materials from this stratum in both units included burned and unburned bone, while in Unit 32 Galiad ware and leadglazed ceramics were also recovered.

As in Units 27-29, Stratum 5 was made up of multiple, thin hard-packed surfaces of a gray tan loamy soil. Within these multiple layers, Goliad ware and lead-glazed ceramics were recovered. Both fragments identified as bovid, ovid, and fish were also recovered from both units. A mano fragment was

found in the last layer removed from Unit 32. Stratum 5 was excavated to a maximum depth of $45 \mathrm{~cm}$ in Unit 32 and $48 \mathrm{~cm}$ in Unit 31 . Excavation was terminated at this depth since no structural evidence was noted in either unit.

Observations: The strata visible in these units are virtually identical to those in Units 27-29, and also in Unit 7 (see Fig. 5).

Units 33 and 34

Units 33 and 34 were also $1-m^{2}$ units placed immediately south of Unit 31 . The south wall of the compound transected the southern portion of Unit 34 (see Fig. 3). Strata 1-3 were identical to the previously discussed units in this area. The ground surface of these units contained noticeably more sandstone rocks than the other units. These sandstone rocks were scattered throughout Stratum 1 in these two units, probably due to the proximity of these units to the crumbling south wall of the compound. Minor rootlet intrusions were noted in both units, and thick root concentrations associated with large clumps of underbrush were removed from Unit 33 .

Strata 1 and 2 were shoveled off as a single layer in these units, and the matrix was examined visualiy for cultural materials. None were recovered. Strata 1 and 2 combined were approximately $25 \mathrm{~cm}$ thick. Stratum 3 , the manure layer, was also removed with shovels in Unit 34 , while in Unit 33 this stratum was removed with trowels and screened. Only bone fragments were recovered. Stratum 3 was approximately $16-20 \mathrm{~cm}$ thick. 
Stratum 4 in Units 33 and 34 was the dark brown black silty loam noted in the previous units, although in these two units this stratum was very uneven, varying in thickness from $2-10 \mathrm{~cm}$. Charcoal and ash were also noted in these units at this level. Small, isolated patches of a reddish tan silty loam were visible in Unit 33 at this level, while in Unit 34 the soil color trended toward a dark blackish color. Small animal bones were recovered from Unit 33 at this level. Feature 3 was first exposed at this stratum in Unit 34 and continued into Stratum 5. Feature 3 was identified as a rodent disturbance which was adjacent to the south wall of the compound and extended across Unit 34. The rodent run extended northward from the wall, into the unit, $6-12 \mathrm{~cm}$.

Below Stratum 4 in these units a thin yellowish tan sandy loam layer was noted. This layer varied in thickness from $1-3 \mathrm{~cm}$ and was more mottled in appearance in Unit 34. It appeared to be slightly thicker, 2-4 cm, and more compact in Unit 34 , than in Unit 33. A grayish tan surface immediately below this thin layer indicated the upper surface of Stratum 5. Unlike previous units, this stratum did not appear to consist of a series of thin tightly packed layers, but instead was a single, very hard surface. This surface trended toward a more yellowish color in Unit 34, containing more sandstone cobbles than in previous units.

Features 4 and 5 were noted in the top of Stratum 5 in Unit 34 . Both of these features were identified as postholes, approximately $25 \times 30 \mathrm{~cm}$ in size (Fig. 6,b). These features extended to a depth of $63 \mathrm{~cm}$ below the surface of the unit. The post associated with Feature 4 appears to have been set sometime after the post in Feature 5 , since the Feature 5 posthole is deeper and the Feature 4 posthole overlaps into Feature 5. They are similar in size, and if an extended line is drawn from the posthole in Unit 7 to the posthole(s) in Unit 34 and continued to the south compound wall, the projected line intersects the wall at an angle of about $90^{\circ}$ (see Figs. 4 and 6,a). Excavation of these units terminated at a depth of $\mathrm{ca} .46 \mathrm{~cm}$ below ground level.

Cultural materials recovered from Unit 33, Stratum 5 included bone, leadglazed ceramics, and chert. In Unit 34, bone, lead-glazed ceramics, and Goliad ware were recovered. One complete blue glass bead and a fragment of another blue bead were recovered from Unit 34 in this stratum.

Observations: The postholes visible in Unit 34 may be associated with the one in Unit 7 . Whether they were associated with a walled structure or perhaps a livestock enclosure is not clear at the present time. The crumbling of the rocks in the south compound wall through aging and weathering may account for some of the soil color changes noted in Stratum 4 of Unit 33. The darker soils noted in Stratum 4 of Unit 34 may be the result of vegetal matter introduced to the stratum by rodents during nesting activities.

\section{Unit 36}

Unit 36 measured one meter east-west by $1.25 \mathrm{~m}$ north-south and was placed one and one-half meters east of Unit 7 to test for additional evidence of structural activity. The north wall of Unit 36 was aligned with the north wall of Unit 7 (see Fig. 3). Strata 1-3 were similar to previous units in 


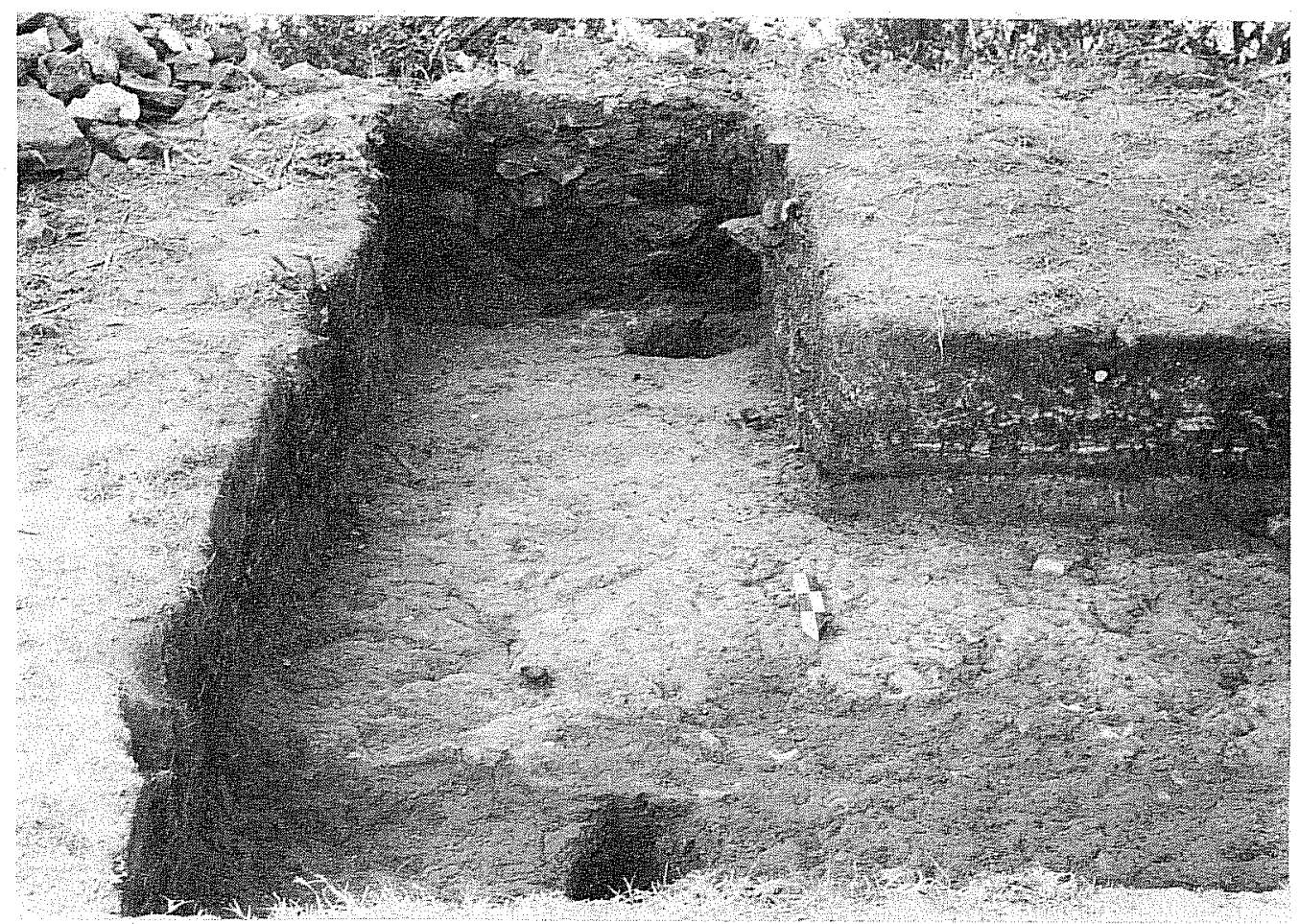

a
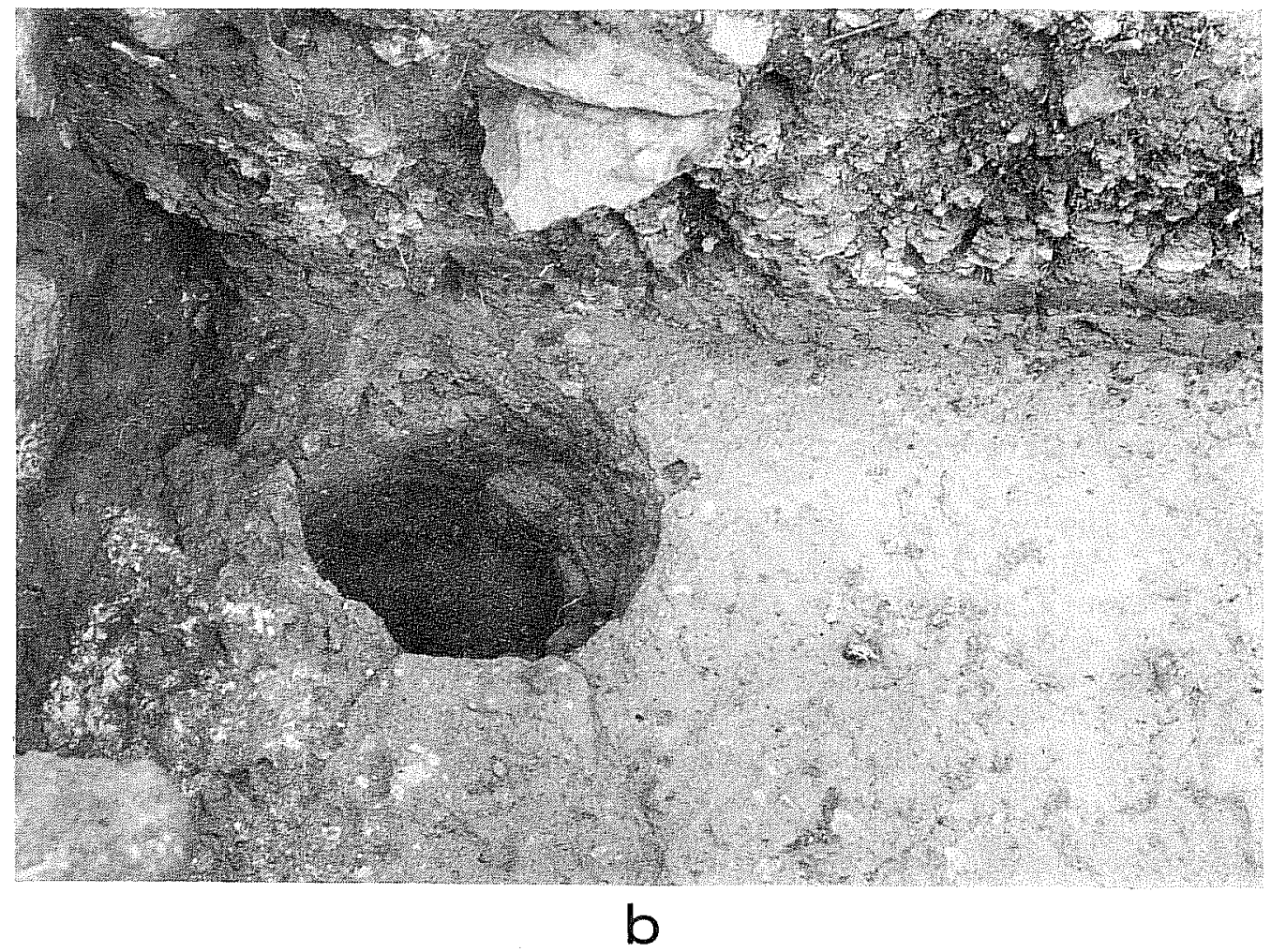

Figure 6. Views in the Southwest Corner. a, postholes in Units 7 and 34, looking toward the south wall. Note the stratigraphy in the south wall of Unit 32--dark layer (Stratum 4) and dung layer above (Stratum 3); b, postholes in Unit 34 (Features 4 and 5), looking west. The south wall is to the left. Note the rodent disturbance along the wall face (Feature 3). The diameter of the postholes is 10 inches. 
the area and were shoveled off to a level just above Stratum 4 . No cultural materials were noted in these strata. Stratum 4, 2-5 cm thick, was troweled and screened. A few small bone fragments were recovered. A profile of the south wall of Units $36,7,27,28$, and 29 is shown in Figure 5.

Stratum 5 consisted of multiple hard-packed surfaces. The soil was a tannish gray loam. In the upper two centimeters (layer 1 of this stratum) only a few bone fragments were recovered. Below this level, two and sometimes three additional layers of the same composition were noted. Cultural materials recovered from these bottom layers included Goliad ware, majolica, lead-glazed and tin-glazed ceramics. A greater amount of bone was also recovered from these lower layers within Stratum 5. The unit was closed out at a depth of approximately $40 \mathrm{~cm}$ when sterile soil was reached. No evidence of construction activity was noted.

Unit 46

Unit 46 was a $1-\mathrm{m}^{2}$ unit aligned with the east wall of Unit 7 . The south wall of Unit 46 was one meter north of the north wall of Unit 7 (see Fig. 3 ).

Except for thickness, Strata 1-3 in this unit were similar to the other units in the southwest corner area. Stratum 1 was 3-6 cm thick, Stratum 2 was 8-10 cm thick, and Stratum 3 was also $8-10 \mathrm{~cm}$ thick. No cultural materials were noted in these strata.

A thin $(2-3 \mathrm{~cm})$ layer of brownish gray, very loose sandy soil was noted beneath Stratum 3 of this unit. Beneath this thin layer, a grayish brown, very hard-packed stratum was exposed. This stratum was composed of several thin layers which readily peeled away independent of each other. Based on these characteristics, this stratum was identified as Stratum 5. Apparently Stratum 4 is missing from the area in which this unit was placed, unless it could be represented by the thin layer below Stratum 3. The bottom two strata were removed with hand trowels and screened. Some bone and Goliad ware were recovered. No evidence of structures was noted.

The Chapel Area Units

Units 30,35 , and 37-45 were placed in the eastern portion of the compound to the south and east of the chapel (Figs. 3 and 5). These units were opened to examine the area for evidence of burial activity associated with the occupation of the compound. Although no burials were found, much evidence concerning activity prior to the construction of the chapel was documented. Evidence of large scale potholing or site looting was also noted during the excavation of these units. Field observations associated with these units are discussed in the following section. 
Units 30 and 35

Units 30 and 35 were parallel units measuring one meter north-south and $4.4 \mathrm{~m}$ east-west. These units were spaced at even intervals between the south face of the chapel and the north wall of Unit 17 (1981 season). The western edges of the units were aligned with the face of the old east compound wall, now nonexistent above ground. The eastern edges of these units were aligned with the eastern edge of Unit 17, resulting in the nonstandard length of $4.4 \mathrm{~m}$ (see Fig. 3). Unit 17 was used as a guide during the excavations of Units 30 and 35 .

Prior to the excavation of Units 30 and 35, a great quantity of sandstone slabs which covered the area had to be relocated. These slabs varied in size and appeared to have been associated with the collapsed walls of the chapel. They evidently had been removed during looting and potholing activities conducted prior to the start of the archaeological investigations in 1980. Many of the slabs were stacked "on end" in loosely formed parallel rows across both units.

Stratum 1 of both units varied from $30-40 \mathrm{~cm}$ thick and consisted of a badly disturbed layer of a loose, reddish tan silty soil in which occasional patches of a yellowish loamy soil were noted. Sandstone rocks and associated fragments were observed throughout this stratum. In the central portions of both units, large accumulations of these rocks were removed. Cultural materials in these units included bone, chert, and glass fragments. A variety of ceramic types was also present and included Goliad ware, lead-glazed ware, and polychrome tin-glazed ware.

Stratum 2 was identified as a more compacted, light gray tan silty soil, varying in thickness from $2-7 \mathrm{~cm}$. The cultural materials associated with this stratum duplicated those of Stratum 1. Sandstone rocks were also present in this layer, but were generally smaller in size and fewer in number.

Stratum 3 in Units 30 and 35 consisted of a layer of gray tan compacted dung varying in thickness from $5-20 \mathrm{~cm}$. This stratum was similar to the corresponding stratum in the southwest corner units. Stratum 3 in both units was noticeably mixed in the eastern portions of the units, resulting in a mixture of sandstone chunks, manure, yellow and red soils, and a gray tan soil. Cultural materials consisted primarily of bone and chert.

Stratum 4 in Units 30 and 35 was a grayish tan, very compacted silty soil in the western portions of the units, and a continuation of the badly mixed matrix in the eastern portions. Features 1 and 2 were identified in this stratum in Unit 30. Feature 1 (Fig. 7), identified as a posthole, was approximately $20 \mathrm{~cm}$ in diameter and extended $22 \mathrm{~cm}$ below the surface of Stratum 4. A shallow trenchlike depression extended from the posthole and continued to the south wall of the unit. The bottom of this depression was $10 \mathrm{~cm}$ below the surface of Stratum 4. The bottom of this shallow trench was characterized by a series of small depressions or indentations. This feature was identified as part of a jacal wall trench. Associated with this feature was a plate fragment and a cluster of bone. Beneath the plate was a small amount of plaster, apparently the contents of the plate when it was discarded. A detailed description of the plaster is presented on page 43. 


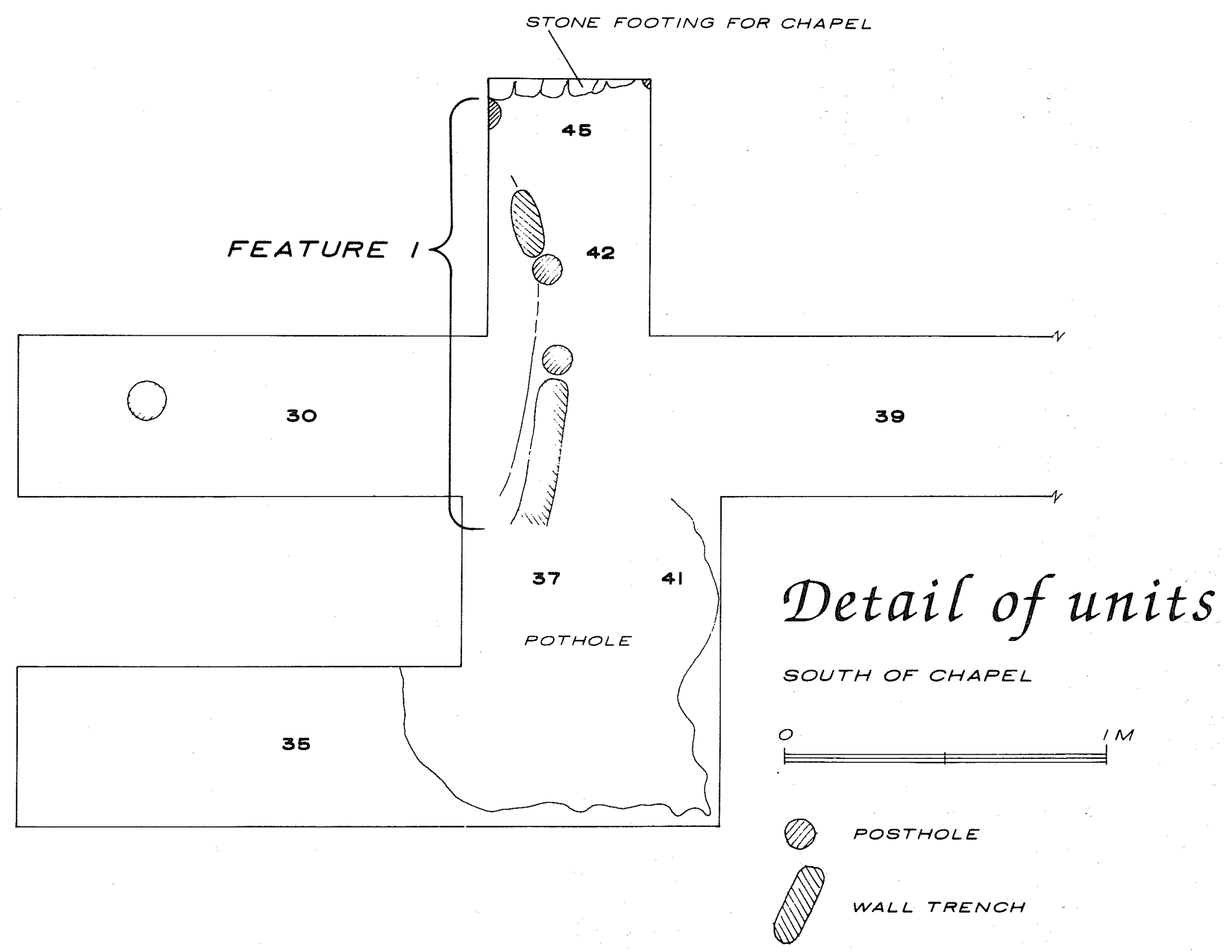

Figure 7. Location of Features South of the Chapel. 
Feature 2 was also identified as a posthole and was located at the west end of Unit 30 at this stratum. The posthole was approximately $25 \mathrm{~cm}$ in diameter and extended $32 \mathrm{~cm}$ below the surface of Stratum 4 . Features 1 and 2 are displayed in Figures 7 and $8, a$.

Cultural materials recovered from Stratum 4 in both units included bone, chert, Goliad ware, and lead-glazed ceramics. Several fragments of tin-glazed ceramics were also recovered, representing several decorative patterns. Freshwater mussel shell and other unidentified shell fragments were also recovered, as were glass fragments, metal scraps, and a cut nail.

Observations: The western portions of Units 30 and 35 appear to be undisturbed and relatively intact below Stratum 3. Both units are badly disturbed and thoroughly mixed in the eastern portions, apparently as a result of multiple, unrelated digging activities. These episodes are evident in the profile drawing of the north wall of Unit 30. A pattern of some sort of structural and occupational activity is evident in Unit 30 . More data needs to be acquired before a more comprehensive interpretation can be offered.

Units 38,39 , and 40

Each of these units was one by two meters in size. Unit 39 was aligned with the east wall of Unit 30, Unit 38 was in the center, and Unit 40 was the easternmost unit along this line (see Fig. 5). Units 38 and 39 were excavated as one unit during the removal of Strata 1,2, and 3 . Unit 40 was excavated independently from Units 38 and 39.

Stratum 1 in Units 38 and 40 varied from $10-20 \mathrm{~cm}$ in thickness and was badly mixed in Unit 39. This stratum was characterized by a reddish brown to brown silty loam soil with much disturbance from grasses and thorny underbrush. The soil color in Unit 40 at this level trended to a slightly grayer color than in Units 38 and 39 . Numerous sandstone rocks and occasional large sandstone boulders were scattered across the surface of these units and appeared throughout Stratum 1 .

Stratum 2, identified in the southwest corner units discussed earlier, was not clearly defined in these units. In Unit 39 this is probably due, at least in part, to the disturbances discussed previously, while in Units 38 and 40, which were comparatively undisturbed, Stratum 2 appeared to be absent.

Stratum 3, the dung layer, was readily visible in Unit 38, the middle unit. It was not visible in any consistent form in Unit 39. Unit 40 was also in a potholed area, but Stratum 3 was noted in undisturbed portions of the unit. Stratum 3 varied in thickness from $10-20 \mathrm{~cm}$. With the exception of Unit 40 , the only cultural materials recovered from the upper strata in these units were bone and chert. What appeared to be a patch of mortar was noticed in Stratum 2 of Unit 39. Because of the disturbed nature of Unit 40, leadglazed ceramic fragments were recovered from the upper strata. As noted earlier, this was the case with the disturbed areas in Units 30, 35, and 41. 


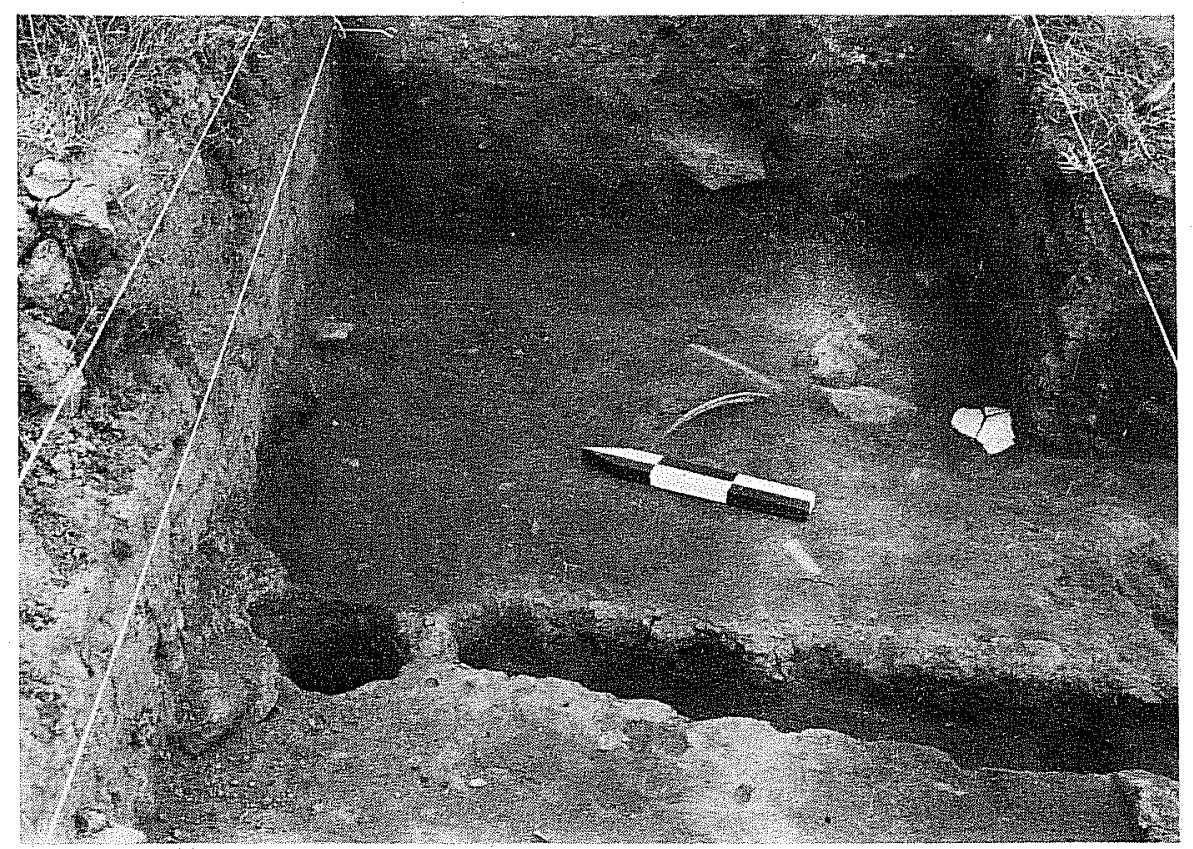

a

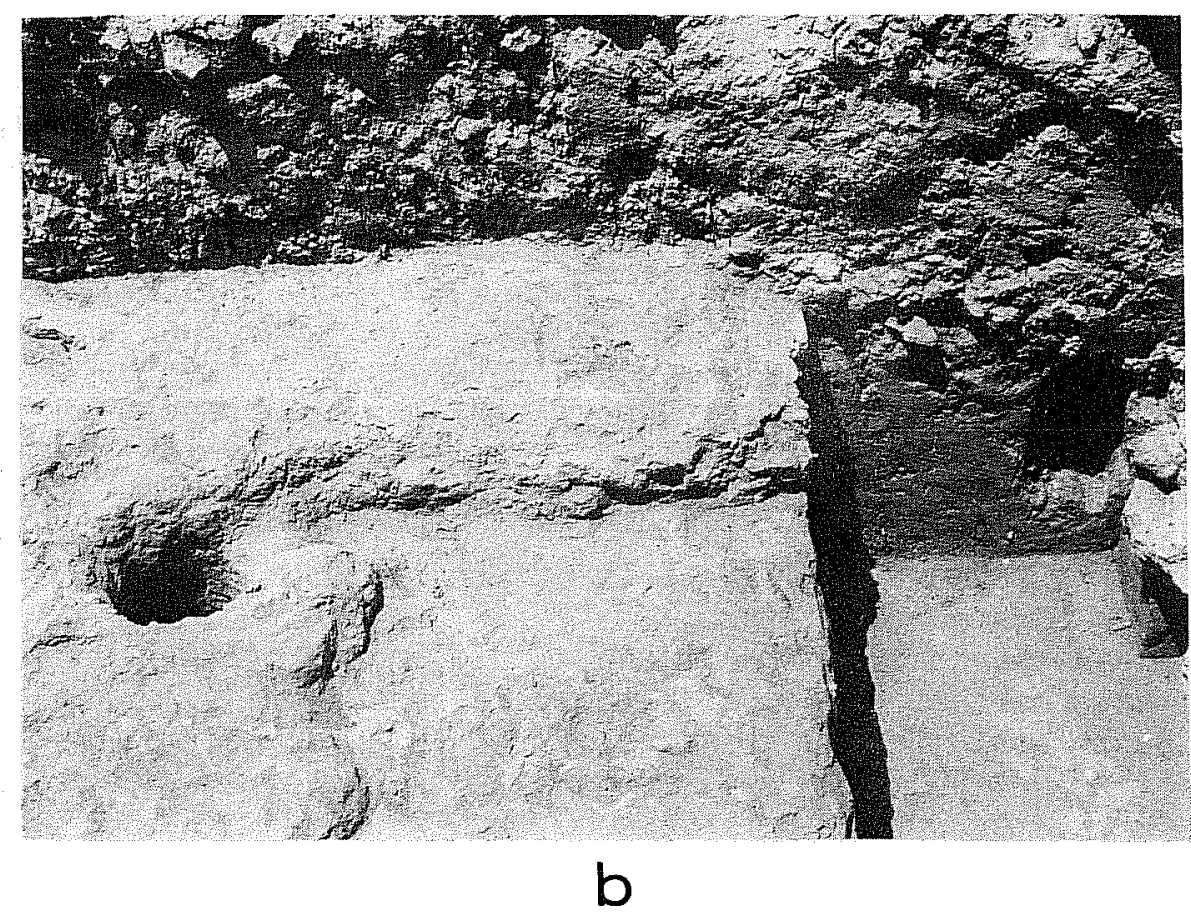

Figure 8. Views in Front of the Chapel. a, east end of Unit 30, before excavation of Units $39,41,42$, and 45 . Jacal trench extends south into Unit 37, where it is obliterated by the pothole (Feature 6). Note large bones and San Elizario plate fragment exposed in the surface of Stratum 5; b, Units 42 and 45 looking west. Note the continuation of the jacal trench across Unit 42, and the posthole in the west wall of Unit 45 . The footing of the front wall of the chapel is visible on the right side of the picture. Note also the continuation of the sandstone chunks of Stratum 4 across the top of the posthole in Unit 45. 
Features 7 and 8 were identified in Stratum 3 of these units. Feature 7 was identified as a disturbed area which started at the western edge of Unit 38 and continued westward across the east central and southern portions of Unit 39. This feature appears to be associated with the disturbance in Unit 41 , but this could not be clearly defined.

Feature 8, another disturbed area, was identified in the southern portion of Unit 40. Approximately $70 \mathrm{~cm}$ in diameter and circular in form, this pit was excavated to a depth of $30 \mathrm{~cm}$ below the surface of Stratum 4 . It appears to have been the result of potholing activities.

Stratum 4 consisted of a gray tan compacted layer immediately below the dung layer and varied in depth from two to three centimeters in Unit 39 to seven to nine centimeters in Units 38 and 40 . As in Units 30 and 35 , as well as the southwest corner units, this stratum (all three units) yielded much in the way of cultural materials. Bone, chert, mussel shell fragments, and miscellaneous shell fragments were recovered from this stratum in all three units, as were Goliad ware, lead-glazed and various tin-glazed ceramics, cut nail fragments, and glass fragments. Some charcoal and ash residue were noted in this stratum. Intermittent patches of 1 ime or plaster were also noted at the base of this stratum (see page 43 for analysis).

Features 9 and 10 were located in Stratum 4 of Unit 39. Feature 9 was circular in form with a diameter of ca. $20 \mathrm{~cm}$ and was void of any cultural materials. Feature 9 may be a posthole, but this could not be firmly established since this feature was relatively shallow compared to other postholes identified during this season.

Feature 10 was another disturbed area approximately $25 \mathrm{~cm}$ in diameter, 1ocated adjacent to the south wall of Unit 39 midway between the east and west walls. Feature 10 was determined to be a rodent disturbance, broken up by root intrusions. Unlike Feature 9, cultural materials were present in Feature 10 and consisted of bone, majolica, Goliad ware, and lead-glazed fragments. Glass fragments were also recovered from Feature 10 along with small flecks of charcoal. The soil in this feature was generally a dark tan color as opposed to the normal grayish tan color of Stratum 4.

Observations: Although evidence of random digging activities was visible in the upper strata of these units, Stratum 4 was essentially intact. Stratum 4 in these units contained much in the way of cultural materials. These materials reflected a pattern consistent with the patterns of most of the other units excavated during this season.

Units 37 and 41

Units 37 and 41 were placed in the balk between Units 30 and 35 (see Fig. 3 ). Unit 37 was a $1-m^{2}$ placed in line with the projected jacal trench 1 ine of Feature 1 in Unit 30. The stratigraphy for the northern $20 \mathrm{~cm}$ of Unit 37 was similar to that of Unit 30, and the jacal trench was located in Stratum 4 in Unit 37 . Unlike Units 30 and 35, a greater amount of cultural 
materials was recovered from Strata 1, 2, and 3 in Unit 37. These materials included Goliad ware, tin-glazed ceramic fragments, and glass fragments. Bone, chert, metal scrap, and cut nail fragments were also recovered from the upper strata of this unit. A fragment of brass was also recovered. The jacal trench stopped abruptly in Unit 37 approximately $20 \mathrm{~cm}$ south of the north wall. This was due to several digging episodes which had occurred in the area of Unit 37.

Unit 41 measures one meter north-south and $60 \mathrm{~cm}$ east-west. The east-west dimension was selected to place the east wall of Unit 41 in 1 ine with the east walls of Units 30 and 35. Due to the badly mixed condition of the strata in Unit 37, Unit 41 was removed by peeling off five centimeter vertical sections from west to east. Each section removed in this manner was examined for evidence of stratigraphic changes which could assist in reconstructing the random digging activity which had occurred in this area. Unit 41 was badly disturbed throughout all levels, similar to Unit 37. Cultural materials recovered from this unit included bone and tin-glazed ceramic fragments of various designs.

The massive disturbed area encompassing most of Units 37 and 41 was designated Feature 6 and was excavated as a separate operation. This feature consisted of multiple disturbances, badly mixed both in terms of cultural materials and stratigraphy. An indication of these multiple disturbances can be seen in the profile drawing of the north wall of Units 30, 38, and 39 (see Fig. 5). Feature 6 was excavated to a depth of $106 \mathrm{~cm}$ below the datum for Unit 30, at which point sterile soil was exposed.

Observations: The disturbances noted in the eastern portion of Units 30 and 35 were more apparent in Units 37 and 41 , encompassing most of the area of both units. The appearance of cultural materials in the upper strata (unlike the basic site-wide trend) and the severe mixing of the soils in these units indicate this area was subjected to repeated potholing and/or looting episodes.

Units 43 and 44

Units 43 and 44 measured one by two meters each, oriented on an east-west axis parallel to and two meters north of Units 38 and 40 (see Fig. 3 ).

Stratum 1 was characterized by a thick layer of fairly loose silty soil, reddish brown in color. This layer varied in thickness from $60-75 \mathrm{~cm}$ and probably represents a mixture of Strata 1 and 2 for the site. A moderate amount of bone representing bovid, ovid, and rodent remains were present. This stratum was removed as a single component in both units and visually examined for cultural materials. Other than bone, no cultural materials were collected. Large reddish sandstone boulders and numerous thick stands of thorny underbrush were present on the surface of these units.

Stratum 2, characterized by a compact gray tan loamy soil in other units in the chapel area, was not visible in these units as a separate layer. Stratum 3 , consisting of a layer of manure, was removed from both units as a single 
operation. Stratum 3 varied in thickness from $50 \mathrm{~cm}$ on the west side of these units to $20 \mathrm{~cm}$ on the east side. No cultural materials were noted in this stratum.

Stratum 4, varying in thickness from three centimeters at the west end of Unit 43 to $25 \mathrm{~cm}$ at the east end of Unit 44, consisted of a grayish tan matrix containing a lot of sandy soil, ash, and charcoal. This stratum was fairly compact, and cobble-sized sandstone fragments were present. Stratum 4 was excavated separately in each unit. Cultural materials recovered from this stratum in these units included Goliad ware and bone. One square cut nail fragment was recovered from Unit 43, and one fragment of Orange Band majolica was recovered from Unit 44. Feature 12 was exposed in Unit 44 at this 1 eve 1.

Feature 12, located in the southwest corner of Unit 44 in Stratum 4, was identified as a $40 \times 70 \mathrm{~cm}$ irregular-shaped stain containing more charcoal and ash than the rest of the unit. This area was noticeably darker in color than the remainder of the unit at this level. Feature 12 was approximately five centimeters deep. This feature appears to have been a shallow basin-shaped pit, but its purpose is not clear at this time. Although Feature 12 contained more charcoal and ash than the rest of the unit, this residue did not appear in sufficient quantity to suggest that this feature was a fire pit.

Feature 13 was located in the southwest corner of Unit 43 in Stratum 4 . This feature was circular in form and consisted of an area of approximately $40 \mathrm{~cm}$ in diameter transcribing an arc from the west wall of the unit to the south wall of the unit. Within this area, the soil was noticeably softer and darker than the surrounding matrix. This difference in soil characteristics was noted for a depth of $20 \mathrm{~cm}$. A second arc, consisting of fist-sized yellowish tan sandstone rocks, surrounded the softer soil area. The arc formed by these rocks was approximately $20 \mathrm{~cm}$ wide and 6-10 cm thick. This second arc was not wel1 defined, and large spaces were noted between the rocks in this arc. Cultural materials recovered from this feature included Goliad ware, bone, and bits of charcoal. A whitish chalky material, similar to lime, was also noted in this feature. Only the portion of this feature that was in Unit 43 was exposed and, as yet, no determination regarding this feature is offered. Exposure of any remaining portion of the feature may assist future evaluations.

Observations: The area in which Units 43 and 44 are located has been subjected to much disturbance, primarily in the upper strata, as a result of the deterioration of the east wall of the chapel and the walls forming the northeast corner of the compound. These disturbances are aggravated further by extensive root disturbances associated with the thick, thorny brush present in the area of the compound.

Units 42 and 45

Unit 42 was positioned north of Unit 30 and aligned with the projected extension of the jacal line and posthole in Feature 1 (see Figs. 3 and 9). Unit 45 was positioned north of, and aligned with Unit 42 . Unit 45 extended northward to the exterior face of the south wall of the chapel. Unit 42 was a $1-m^{2}$ unit, and Unit 45 measured one meter east-west and $60 \mathrm{~cm}$ north-south. 


\section{Profiles}

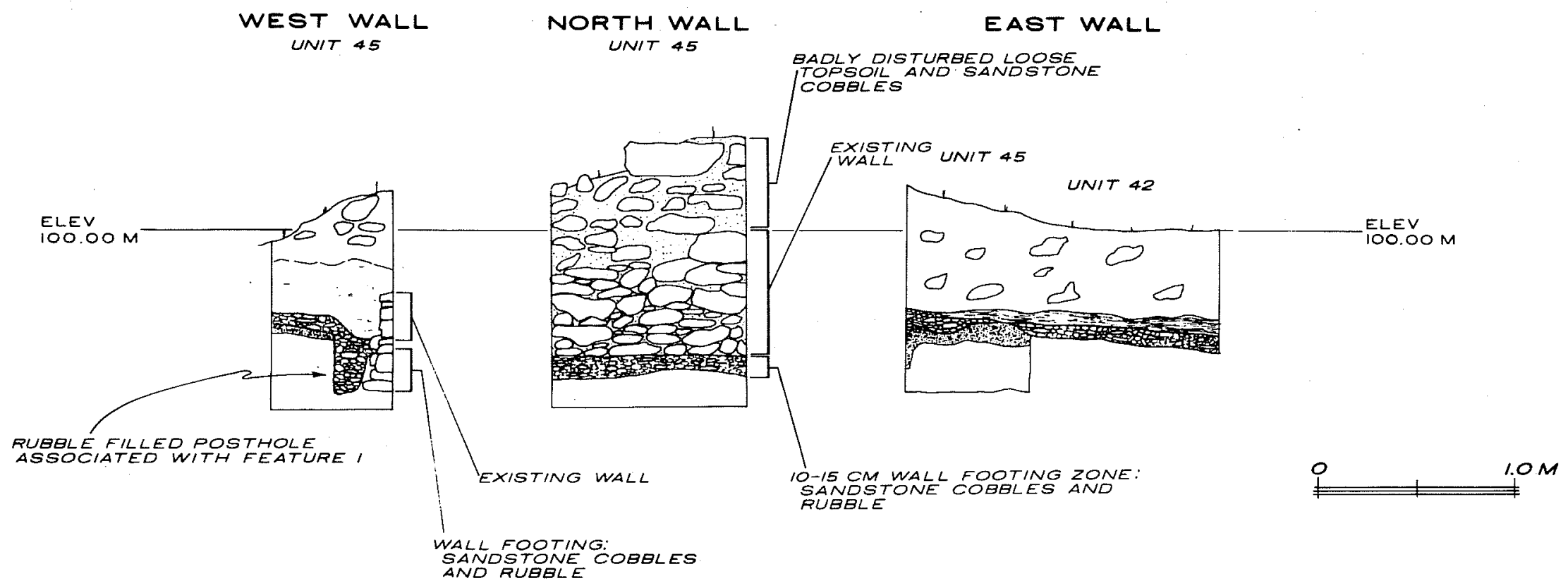

PS REDDISH TAN SILTY LOAM, BADLY DISTURBED; PROBABLY STRATA I AND 2 MIXED

- REDDISH BROWN SILTY LOAM WITH SOME DUNG; STRATA 2 AND 3 MIXED

anIMAL DUNG; STRATUM 3

TIGHTLY COMPACTED RED AND YELLOW SANDSTONE RUBBLE

WID TIGHTLY COMPACTED TAN TO GRAY SILTY LOAM; STRATUM 4

$\square$ VERY TIGHTLY COMPACTED MEDIUM TO DARK GRAY SILTY LOAM WITH CHARCOAL FLECKS: STRATUM 5

Figure 9. Profiles of Unit 45. 
Unit 45 was excavated to a depth of one meter. Unit 42 was excavated to a depth of approximately $70 \mathrm{~cm}$. These measurements are in reference to a datum established for Unit 42 (see Fig. 4).

Strata 1 and 2 of these units were heavily disturbed and virtually indistinguishable from each other. This mixing appears to be the result of looting activities associated with removing the deteriorating walls of the chapel, rather than subsurface potholing activities. This first layer varied in thickness from 40-60 cm due to the steep slope of the ground surface in this area. The slope declines to the south. This layer was removed with a shovel, and the soil was visually examined for cultural materials. Very few bone fragments were recovered from this layer, and one chert fragment was recovered from Unit 42 .

Stratum 3, the dung layer, was visible in both units, varying in depth from five to seven centimeters. This stratum thinned noticeably in Unit 45 and disappeared as it approached the south wall of the chapel (see Figs. $8, b$ and 9).

Between Strata 3 and 4 was a layer of reddish sandstone rubble, tightly compacted, with almost no soil matrix. This rubble layer was $10-12 \mathrm{~cm}$ thick and appears to be associated with the construction of the chapel. The northernmost posthole associated with Feature 1 (visible in the west wall profile drawing of Unit 45, Fig. 8,b) was filled with this rubble, and similar rubble was noted in the wall footing for the south wall of the chapel. A mortar sample from this wall was taken (see page 43 ).

Stratum 4, excavated only in Unit 45, consisted of a tightly compacted tan to gray silty soil approximately four to eight centimeters thick. Bone, majolica, Goliad ware, lead-glazed and tin-glazed ceramic fragments were recovered from this stratum. Similar artifacts were removed from another posthole in Unit 42 , also associated with Feature 1, but not from the posthole in Unit 45.

Stratum 5, in Unit 45, was excavated to an arbitrary depth of one meter below the Unit 42 datum. At the $75-80 \mathrm{~cm}$ level of this stratum a thin line of charcoal flecks was noted in the walls of the unit. Mussel shell fragments were also recovered from Unit 45 at this level. Stratum 5 was tightly compacted, as was Stratum 4, and was characterized by a medium to dark gray silty soil. Artifacts recovered from this stratum were similar to those recovered from Stratum 4 .

Observations: Apparently the postholes in Units 42 and 45 are associated with Feature 1, first exposed in Unit 30. If there is such a connection, it would appear that the structure associated with these postholes predates the chapel. This is based, in part, on the fact that the sandstone rubble filled the posthole in Unit 45, indicating that the posthole was in existence when the chapel walls were constructed. A marked increase in soil compactness was noted on the west side of the jacal/posthole line compared to that of the soil on the east side of the jacal/posthole line. This may indicate one side served as a living floor and, as such, was subjected to a greater concentration of traffic activity, i.e., walking, standing, etc., while the other side received a noticeably less degree of similar activity. 
The Test Pits

Two $50 \times 75 \mathrm{~cm}$ test pits were also excavated during the 1982 season. Each unit was excavated to a depth of $75 \mathrm{~cm}$ below ground level. The starting elevation for Test Pit 1 was 98.95, and the starting elevation for Test Pit 2 was 99.84. Test Pit 1 was placed in the open field $22.6 \mathrm{~m}$ north of the north wall of the compound, and Test Pit 2 was placed in the west central portion of the compound, separate from ongoing excavation activities.

The purpose of these units was to expose stratigraphic sequences within the occupation area and apart from the occupation area for comparison purposes. Data obtained from this comparison may contribute to interpreting the changes in the natural stratigraphy caused by human occupation in a given area over a period of time.

The stratigraphy in Test Pit 1 consisted of a reddish tan silty soil which gradually trended through various gradations of tan and yellow into a whitish yellow, hard-packed soil containing caliche nodules. Beneath this level, a consistent, uniform bed of caliche was evident. The soil color changes were very gradual, and the identification of any specific, intermediate stratum was difficult. The change was most evident when observing the top and bottom layers. No disturbances below the plow zone, ca. 15-20 cm thick, were noted. No cultural materials were noted.

Four distinct soil zones were identified in Test Pit 2. Zone 1 was a reddish brown silty soil, containing rootlets and sandstone rocks. With the exception of these rootlets and sandstone rocks, this zone was comparable to the upper portion of Test Pit 1.

Zone 2 was a very hard-packed, dark gray soil comparable to Stratum 4 identified in the excavation units. Stratum 4 was the layer in which most of the cultural materials were recovered. The dung layer was not visible in this pit. Had it been present, it should have overlain this zone.

Zone 3 was a yellowish gray transition zone containing some caliche. This zone graded into Zone 4, a layer of tightly compacted clayey soil, containing caliche nodules and trending into a caliche base. The lower zones of Test Pit 2 resemble those of Test Pit 1 .

In comparing these two stratigraphies, it appears that the gray strata, which have been identified across the site (Strata 4 and 5), are confined to the compound area and are a result of occupational activities and not simply the surface which existed when the area was first occupied. Future test units, spaced at predetermined intervals transecting the site and the surrounding area, may permit a more detailed analysis of the influences that occupational activities have had on the natural stratigraphy. 


\section{CULTURAL REMAINS}

The artifacts recovered in this year's excavations are considerably fewer and less varied than in previous years. This is primarily due to the fact that no work was done in the trash pits, where artifact counts are understandably high. By far the largest category recovered, both in volume and in weight, is animal bone (see the Appendix for provenience of all bone recovered during this season). Next lower in quantity are the ceramics, which make up the most important part of the rest of the collection in terms of information they provide on dating and the relationships between strata and excavation units. In addition, a few sherds of glass, two beads, and some metal objects round out the collection.

We will first describe the various categories, then discuss their implications for interpretation of the excavation units in which they were found. Comparison will be made with similar artifacts found at Rancho de las Cabras in previous years and those found at other Spanish sites in Texas.

Bone (William McClure)

The following species are represented in the faunal collection:

Channel catfish

Freshwater drum

Unidentified fish

Toad

King snake

Rat snake

Water turtle

Common snapping turtle

Softshell turtle

Unidentified turtle

Turkey

Chicken

Turkey vulture

Bobwhite

Unidentified bird

Opossum

Bat

Eastern cottontail

Rock squirrel

Pocket gopher

Pocket mouse

White-footed mouse

Hispid cotton rat

Southern plains woodrat
Ictalurus punctatus

Aplodinotus grunniens

Genus unknown

Bufo sp.

Lampropeltis either calligaster or getulus

Elaphe cf. obsoleta

Pseudemys sp.

Chelydra serpentina

Trionyx sp.

Genus unknown

Meleagris gallopavo

Gallus domesticus

Cathartes aura

Colinus virginianus

Genus unknown

Didelphis virginiana

Genus unknown

Sylvilagus floridanus

Spermophilus variegatus

Geomys sp.

Perognathus sp.

Peromyscus sp.

Sigmodon hispidus

Neotoma micropus 


$\begin{array}{ll}\text { Fox (?) } & \text { cf. Urocyon cineroargentatus } \\ \text { Dog } & \text { Canis familiaris } \\ \text { Spotted skunk } & \text { Spilogale cf. putorius } \\ \text { Pig } & \text { Sus scrofa } \\ \text { Collared peccary } & \text { Tayassu tajacu } \\ \text { White-tailed deer } & \text { Odocoileus virginianus } \\ \text { Cow } & \text { Bos taurus } \\ \text { Goat } & \text { Capra hirca } \\ \text { Sheep } & \text { Ovis aries } \\ \text { Horse } & \text { Equus caballus } \\ \text { Unidentified mammal } & \text { Genus unknown }\end{array}$

Distribution of Bones of Small Animals

The excavation yielded 190 separate bones of hispid cotton rat. The condition of the bones is better than that of the domestic stock. The bones probably were not cooked. All parts of the body are represented. The most probable source of these bones is owl pellets. Only two of the rat bones came from the southwest corner area with all others from the chapel area.

In the chapel area, Feature 6 is a large disturbed area. The part of Unit 37 that is outside of Feature 6 had one rat bone each in Strata 1 and 3 with 83 $(44 \%)$ in Stratum 2. This suggests that an owl's roost was directly above Unit 37 when Stratum 2 was at the surface; that the primary drop zone was protected from scattering by stock or the site was not occupied at the time; and that there was little disturbance of Unit 37 (outside Feature 6) after the owl was there. Part of Feature 6 within Unit 41 was excavated without screening and yielded no small animal bones. The balance of Feature 6 contained nine rat bones which helps confirm that the disturbance was after the owl left.

Units 30 and 35 are on opposite sides of Unit 37 . Strata 1 and 2 of Unit 35 had $26(14 \%)$ rat bones, while in Unit 30 there were only three rat bones in Stratum 2. Stratum 3 of Unit 35 had 10 rat bones indicating that it was disturbed, while Stratum 3 of Unit 30 had none. The eastern part of Stratum 4 was disturbed in these two units. The west part of Unit 35 had three rat bones, the central part had two, and the eastern part had $38(20 \%)$; Unit 30 had none. This suggests that the peliet drop zone included Unit 35E.

One rat bone was found in Stratum 3 of Unit 38 and three in Stratum 4 of Units 38 and 39. Features 7 and 8 had three rat bones, but there were no others found in Unit 40 . Unit 42 had one rat bone in Stratum 3, and Unit 43 had two in Strata 1 and 2 and two in Stratum 4. Features 1 and 2 had no rat bones and their fill predates the owl period, and they were somehow spared from the modern disturbance.

The excavation yielded 22 separate bones of cottontail rabbit. The condition of the bones is similar to that of the hispid cotton rat, and they are probably also from owl pellets. Only one of the bones came from the southwest corner area. In the chapel area, distribution of rabbit bones is similar to that of the cotton rat with seven (33\%) from Stratum 2 of Unit 37, five (24\%) from 
Strata 1 and 2 of Unit 25, and two from Feature 6 . One bone came from each of the following units: Unit 30, Layer 2; Unit 30, Layer 4W; Unit 38-39, Layer 4; Unit 39, Layer 6; Unit 42, Layer 1; Unit 42, Layer 3; and Feature 7.

In the chapel area, there were bones of a few other small animals that are known to be preyed upon by owls. These included one bone each of spotted skunk, pocket mouse, bobwhite; two bones of woodrat; three bones each of pocket gopher and bat; six bones of rock squirrel; and seven bones of rat snake.

If these small animals are all attributable to the activity of owls, the distribution away from the drop zone is probably due to something other than the modern disturbances. The scattering could have been by stock with only a part of the drop zone protected from traffic.

In the southwest corner area the bones recovered included a few smaller animals that also could have been food items of owls. These include hispid cotton rat (two in Unit 27-28, Layer 8), rabbit (Unit 27-28, Layer 7), rock squirrel (two in Unit 31, Layer 5 and Unit 36, Layer 6), woodrat (Unit 27-28, Layer 7; Unit 27-28, Layer 8), and king snake (Unit 27-28, Layer 5). These items are from lower strata and are less concentrated than those in the chapel area.

\section{Bone Modification}

Most of the bones are in good but friable condition. Many show the usual cracks, splits, and surface alteration due to soil conditions and age. A few had been burned. Some damage occurred during recovery and transport. Except for a scapula, metapodials, and small compact bones, all of the cow bones had been broken by impact, probably for marrow extraction. The bones of deer, goat, and sheep (DGS) were in similar condition, except that a few more long bones were intact.

Onty five bones were found to have been gnawed by rodents. A DGS rib had been perforated in the area of the head by teeth of a dog-sized carnivore.

Many of the cow bones and a few of the DGS bones have marks that indicate butchering practices. There are no marks from stone tools or metal saws. Cut marks, apparently from sharp metal knives, are on skull fragments, femurs (two, one for removal of tibia), tibia, lumbar vertebra, cervical vertebra, neural spine, scapula, metapodials (three), long bones (two), and ribs (12). Chop marks, apparently from metal axes, are on vertebrae (two), long bones (two), and ribs (seven). Hack marks from either hatchets or machetes are on radius, humerus, cervical vertebrae (six), thoracic vertebrae (six), lumbar vertebrae (four), neural spines (eight), ribs (21), sacrum, and long bones (two).

Some cut marks on ribs are two to three millimeters apart, but most are much farther apart. One cow metapodial has numerous straight, non-parallel, cut marks on the flat side and a few on the convex side. These are too numerous to have been due to skinning. One cow radius had been hacked both longitudinally and transverse. A hatchet mark on a vertebra shows two edges at right angles. A hatchet used on the concave side of a DGS sacrum could have had a cutting edge no longer than $30 \mathrm{~mm}$. 
None of the cow vertebrae had intact neural spines. Either they had been hacked off by machete or broken off by impact. Six cow and nine DGS vertebrae (cervical, thoracic, and lumbar) had been hacked completely through the centrum, always at a slight angle. Many ribs were hacked into pieces ranging from three to $20 \mathrm{~cm}$.

One bone artifact made from a cow rib may have been used as a tool. It is illustrated below.
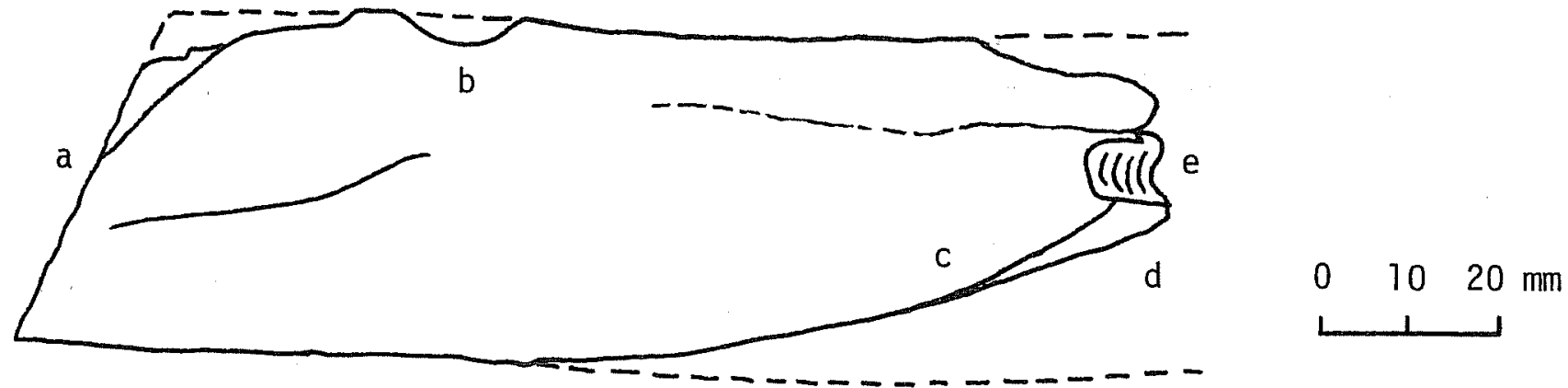

BOVID RIB (38-39/3-DI Feature 7)

$a=$ straight cut with impact from other side

$\mathrm{b}=$ notch

$c=$ grooved and snapped along curved line

$d=$ highly polished, convex face

$e=$ flake scar, perhaps from failure of tool during use

\section{Discussion}

During the 1982 season, $19 \mathrm{~kg}$ of bones and bone fragments were recovered. Nine kilograms are unidentified fragments of which about $75 \%$ are probably cow and $25 \%$ deer, goat, or sheep. Cow bones weighed $7600 \mathrm{~g}$. Deer, goat, and sheep bones weighed about $500 \mathrm{~g}$ each, and the undifferentiated DGS bones weighed one kilogram. The other species recovered had less than $50 \mathrm{~g}$ each. The bones of the four species were distributed throughout the southwest corner area and the chapel area in about the same ratio as the excavation effort.

Of the 102 lots, 41 included one or more burned bones. In these 1ots 10\% of the bones were burned. The distribution of the burned bones is about the same as total bones. Most of the bones, as well as the burned bones, are from lower strata, reflecting disposal during the earlier, more intense, occupation. The burned bones are nearly all unidentifiable fragments. They probably represent contact with fire other than while that particular item was being cooked.

Bones from all parts of the body of the four major species are in the collection. Butchering and disposal were both done on the premises. Cervical vertebrae of cow are significantly underrepresented. Perhaps the neck was given to dogs who chewed up the bones. 
Butchering was probably accomplished by use of tools such as metal knives, axes, and hatchets. Cows were slaughtered at a young age as most long bones and 79\% of vertebrae did not have both epiphyses fused. DGS were butchered at an older age as only $53 \%$ of vertebrae did not have the epiphyses fused.

Other food items found in both parts of the site include pig, peccary, fish, turtle, chicken, and turkey. None of these were a significant percentage of a diet.

Small animal bones that are probably from owl pellets were found, mostly in the chapel area. These include hispid cotton rat, cottontail rabbit, rock squirrel, woodrat, pocket mouse, pocket gopher, white-footed mouse, bobwhite, bat, king snake, and rat snake. Other nonfood animals found were horse, dog, fox, vulture, toad, and opossum.

Some sort of structure was used as a roost by owls in Unit 37. A tree is not likely as the roost postdates the deposition of the dung stratum during which time a tree probably could not have survived. The structure may have been a wall as the rat bones were prevented from being scattered in a northerly direction.

\section{Ceramics}

Unglazed Wares (190 sherds)

The largest number of sherds found during this season consisted of the hand-formed, unglazed type customarily called Goliad ware when found in historic contexts. It closely resembles the ceramics made in south Texas in prehistoric times, and probably represents the continuation of that type into the Historic period (Ivey 1983; Fox, Bass, and Hester 1976:67). The sherds vary in color from tan through red brown to black and generally have a dark core as the result of being fired in the open air. Numerous white flecks of bone temper are visible on most surfaces. Vessel shapes include shallow bowls with rounded bottoms and fully rounded jars and ollas. Sherds of this ware are plentiful on Spanish sites in south Texas.

Lead-Glazed Wares (71 sherds)

This is a wheel-turned ware with a glaze primarily on the interior of vessels such as bowls and ollas. The color of the glaze varies from deep caramel to pale yellow and shades into greens. Some bowls have a green band on the rim and/or in the bottom (Fig. 10,f). The red brown, sandy paste is diagnostic of this type (see Fox 1974:56). These vessels were probably made in the pottery centers around Mexico City. Judging from observation of present-day use, they would have been used for cooking and serving. Lead-glazed wares comprise a large portion of the ceramic collections from mid-18th century Spanish sites.

Included in the total sherd count for this type is one sherd of green-glazed olive jar such as described by Goggin (1964), found in the first level of Unit 35. Jars of this type were used primarily for transportation and storage. 
While a few sherds are found on inland sites, these heavy, thick-walled jars are more prevalent on coastal sites where they would have been transported by ship, perhaps directly from ports in Europe and the Mediterranean. Those which migrated inland were no doubt used and reused as containers until they finally were broken and discarded.

Another lead-glazed type (three sherds) has a dark, mahogany brown-glazed surface which is the result of the red body showing through a thin, nearly colorless lead glaze (Fox 1974:59). Fragments are too small to determine vessel shape, but larger sherds recovered from Mission Rosario (ibid.) were from thin-walled, shallow, flat-bottomed bowls. This type has been called Guadalajara Red Ware by Schuetz (1969:51), suggesting that area of Mexico as its source.

Tin-Glazed Wares (74 sherds)

These consist primarily of majolicas made in Puebla and Mexico City. Tin-glazed wares are of interest not only because of their attractive, brightly colored decoration, but because they passed into and out of fashion in sufficiently rapid succession to allow their use as an aid to dating sites and/or deposits within them.

Types decorated in blue on a white background include fragments of deep plates of a variation of blue-banded Huejotzingo (Fig. 10,b) popular from about 1770 to 1800 (Barnes and May 1972:32) or possibly a bit later (Seifert 1977:16). Also represented are cups and bowls bearing light blue bands and floral designs (Fig. 10, c,d). Little has been done so far to break down the large quantities of blue decorated majolicas into specific, dated types. Therefore, a careful analysis in the future of all sherds excavated at Rancho de las Cabras, which was occupied within a limited time frame, should contribute a great deal of information in this regard.

As in the past two seasons, the most prevalent majolica variety found was San Elizario (Fig. 10,i), decorated with a blue band bordered with brown 1 ines and pendant flowers touched with brown accents. A crane stands in the center of the typical deep plate. This type was popular in northern Mexico during the last half of the 18th century (Gerald 1968:46) and in Texas after about 1760 (Ivey and Fox 1981:35).

of the polychrome majolica sherds recovered, all but one appear to represent one distinctive orange-banded pattern (Fig. 10,a) which has not as yet been isolated as a variety, since only a portion of the overall design can at present be reconstructed. Hopefully future excavations will yield additional portions of the overall design. Sherds bearing this same design have been found in a number of other Texas sites, including Mission Rosario (Texas Archeological Research Laboratory, Austin, Texas, collections), Mission San Juan Capistrano (Schuetz 1969:Plate 27,J), and the Alamo (CAR-UTSA collection).

The balance of the sherds are plain white and appear to represent undecorated areas of blue on white vessels. One small sherd of plain white tin-glazed ware has the softer, yellowish paste and flaking glaze typical of French faience 
Figure 10. Selected Artifacts from 1982 Excavations.

a, polychrome majolica plate, orange banded pattern. Rim band is orange with brown borders. Design includes yellow and green balls, outlined with brown black and blue dots. Sherds in this fragment are from Unit 30, Layer 4E; Unit 35, Layers 1 and 2; and Unit 38-39, Layer 4 indicating how much disturbance has taken place in this area of the site;

b, blue-on-white majolica plate, wavy edged variety, from Unit 35, Layer 4W;

c,d, blue-on-white majolica cup, from Unit 38, Layer 6;

e, aquamarine bottle fragments from Unit 39, Layer 6;

f, lead-glazed bowl with green bands from Unit 38-39, Layer 4;

g, chain link, probably from rein chain of bridle bit (see Ivey 1983:

Fig. 4,g) from Unit 27-28, Layer 5;

$h$, back half of compound button from Unit 43-44, Layer 6;

$i$, San Elizario plate from the surface of Unit 30, Layer 5E. 

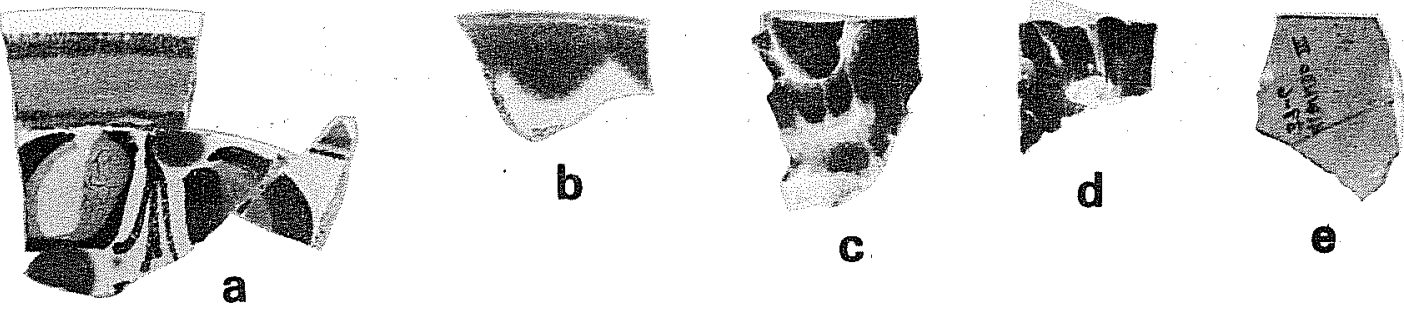

c.

e

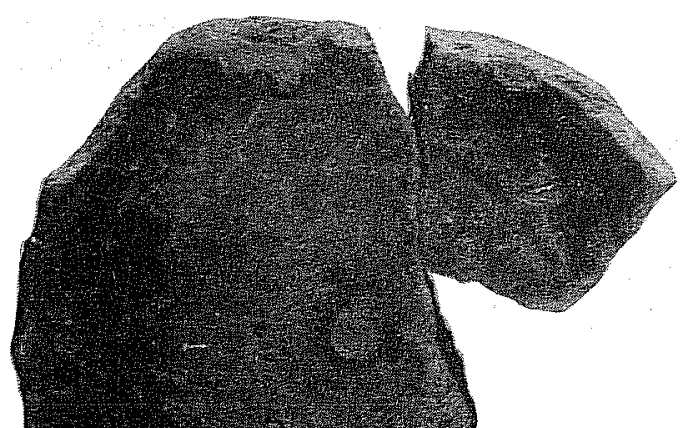

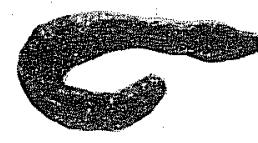

g

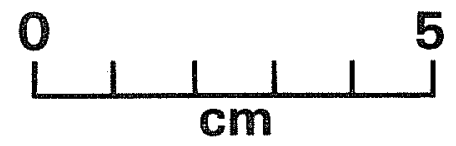

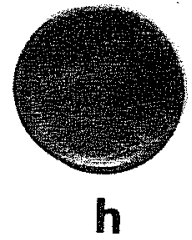
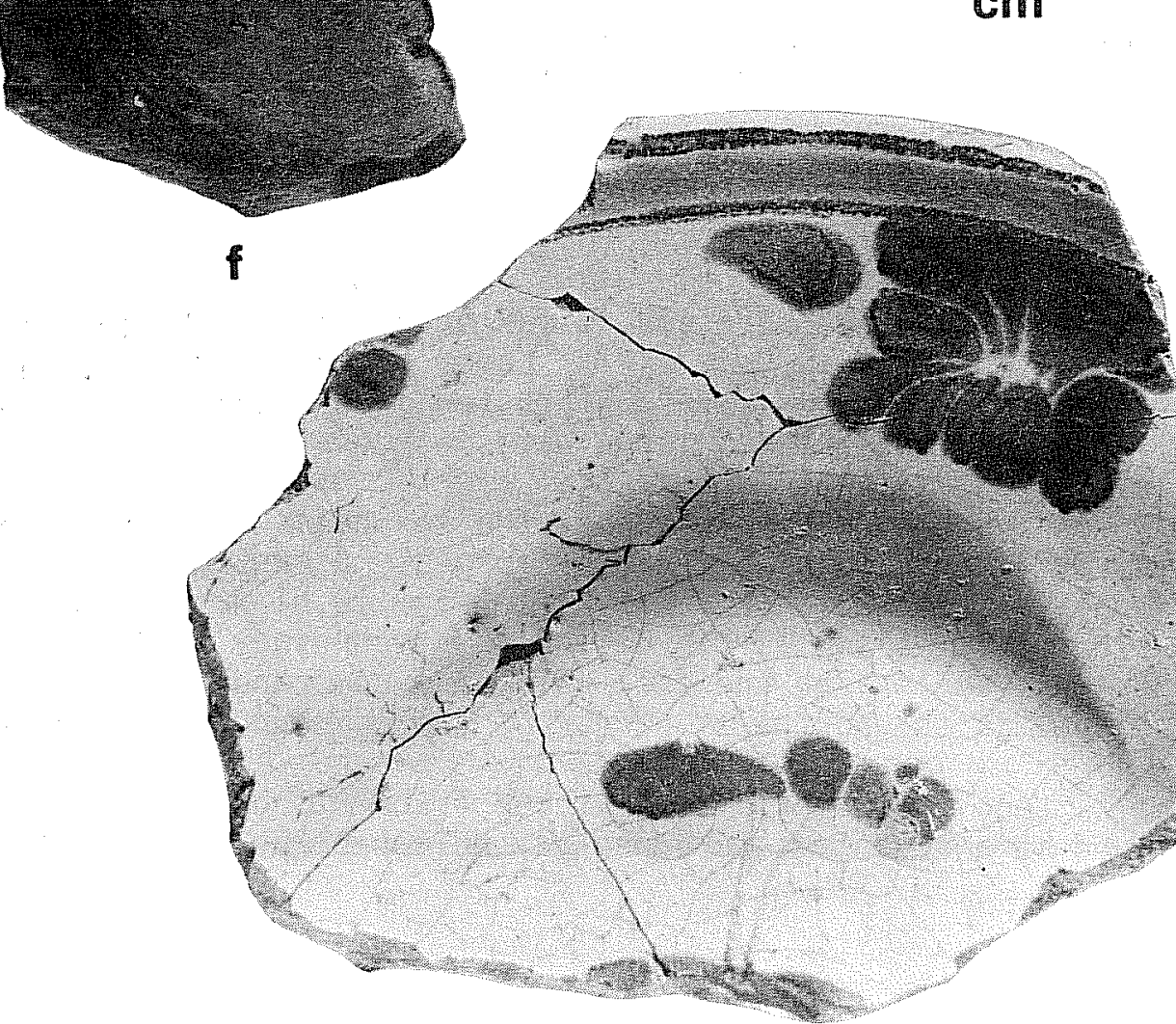
(Tunnel1 and Ambler 1967:35). One or two sherds of this ceramic type are generally recovered from each excavation at Spanish sites in the San Antonio area. One was found at Rancho de las Cabras last year and two the year before.

G1ass

Twelve fragments of glass containers were recovered this season, all from the area in front of the chapel. Of these, one from Unit 30 is from a beer or whiskey bottle of 19th-century vintage. Three from Unit 37 are olive green fragments of a wine bottle similar to those frequently found on 18th-century Spanish sites as well as on 19th-century Anglo-American sites. The balance are very thin aquamarine fragments (Fig. 10,e) which are probably from pharmaceutical bottles used in the 18th century (see Ivey and Fox 1981:35). These were found in the fill of Feature 6 , the deep pothunter's pit.

Two sma11, blue glass trade beads were recovered from Unit 34 in the southwest corner of the compound. Both appear to be R. K. Harris' Type 48 (Harris and Harris 1967:144) which, he remarks, occurred in Texas in smal1 numbers from 1700 to 1767 and in larger numbers between 1767 and 1836. This same type has been recovered from all the San Antonio missions (CAR-UTSA collections) and in both previous excavations at Rancho de las Cabras (see Ivey and Fox 1981:36; Ivey 1983).

Metal

Four fragments of metal recovered have not so far been positively identified. A curved, badly rusted object from Unit 27-28, Layer 5, may be part of a bridle chain link (Fig. 10,g). Two chunks of rusted iron found in the jacal trench (Feature 1) may be fragments of large nails. A flat fragment of brass with two beveled edges found in Unit 37, Layer 2, may be from some sort of decorative hardware used in the chapel. Of the six nails recovered, only one can be positively identified as being hand forged. A cast brass button with a slightly concave face and a drilled shank (Fig. 10,h) was found in Unit 43-44, Layer 6. This is similar in design and technology to others found in Spanish sites, and may be the back half of a compound button similar to one found last year in the northwest corner of the compound (Ivey 1983).

The only other metal recovered consisted of three fragments of a rusted beer can. This was found in a recent disturbance at the top of Unit 37 in front of the chapel.

Stone

A total of 117 fragments of chert found in this year's excavations reinforces our impression that the use of stone tools continued throughout the 18th century in the San Antonio River valley (see Ivey and Fox 1981:37; Ivey 1983). Although no actual artifacts were found, the debitage would suggest an active chert industry on the site. 
A pestle or mano fragment made of fine-grained, gray sandstone was found in Unit 32, Layer 8b. It is well smoothed on all surfaces and, in addition, bears scars on one side as if it had been used as a hammer as well as for grinding.

So i1, Mortar, and Plaster

One soil sample, two plaster samples, and one mortar sample were examined during the analysis of this season's field work. These samples were examined under a binocular microscope with a magnification range of $14 \mathrm{X}$ to $80 \mathrm{X}$. The following observations were noted.

Mortar Sample from Chapel Wa 11: A sample of the mortar used on the exterior face of the south chapel wall was passed through a number 35 geological sieve, and the remaining matrix was examined under a lighted microscope. The original sample appeared to be a medium brown fine-grained mud. The examination of this sample revealed a very high $(80 \%)$ content of cryptocrystalline quartz. The grain size varied from one to five millimeters in diameter and were primarily translucent, although occasional opaque crystals were present. Snail shell fragments (Rabdotus) and small sandstone fragments were also present. Minute fragments of breccia were noted. The color of the opaque crystalline crystals varied from a pale yellow to a medium red to a dark, almost black purple color.

So il Sample From Unit 27-28, Stratum 4: This sample was passed through a number 35 geological screen, and the remaining matrix examined under a lighted microscope. This sample consisted primarily of a fine-grained silty soil. The grain size appeared to be ca. $0.3 \mathrm{~mm}$. Grain color varied from cream to grayish tan. Occasional translucent and opaque quartzite crystals were noted. Occasional minute flecks of charcoal and small bone fragments, as well as decomposing vegetal matter, were also noted in this sample.

Plaster Sample from Unit 39, Layer 6 (Stratum 4): This sample was almost 100\% 1 ime. An occasional opaque or translucent quartzite crystal, usually less than one millimeter in diameter, was noted.

Plaster Sample in Plate from Feature 1 (Unit 30, Stratum 4): This sample consisted of 1 ime mixed with bone fragments. The bone fragments had been pulverized into minute fragments, linear in shape and unidentifiable. Occasional, isolated quartzite crystals, both opaque and translucent, were present. Irregular patches of a gray clayey soil were noted on the outer surfaces of this sample, but appear to be foreign intrusions and not an integral part of the plaster.

\section{Artifact Discussion}

The artifacts from this year's excavations (see Table 1), while fewer than those found in other years, represent the same basic types and time period, as might be expected. It is interesting to note the absence of porcelain, burnished wares, black luster, and Galera ware in the collection this year. Since these 
TABLE 1. PROVENIENCE OF CULTURAL REMAINS FROM 1982 SEASON

\begin{tabular}{|c|c|c|c|c|c|c|c|c|c|c|c|c|c|c|c|c|c|c|c|}
\hline \multirow[b]{2}{*}{ Unit } & \multirow[b]{2}{*}{$\begin{array}{l}\text { IWEST } \\
\text { IER } \\
\\
\text { Layer/ } \\
\text { Feature }\end{array}$} & \multicolumn{7}{|c|}{ CERAMICS } & \multirow[b]{2}{*}{ 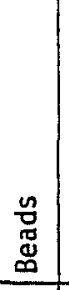 } & \multirow[b]{2}{*}{ 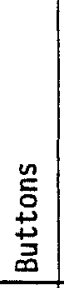 } & \multirow[b]{2}{*}{$\begin{array}{l}0 \\
0 \\
0 \\
0 \\
0\end{array}$} & \multirow[b]{2}{*}{ 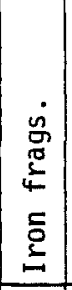 } & \multirow[b]{2}{*}{$\begin{array}{l}气 \\
\bar{z} \\
\Xi \\
E\end{array}$} & \multirow[b]{2}{*}{ 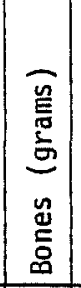 } & \multirow[b]{2}{*}{ 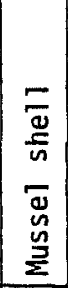 } & \multirow[b]{2}{*}{$\frac{n}{\frac{\pi}{2}}$} & \multirow[b]{2}{*}{ 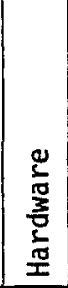 } & \multirow[b]{2}{*}{ 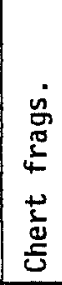 } & \multirow[b]{2}{*}{ 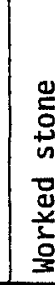 } \\
\hline & & 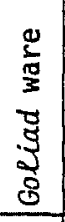 & 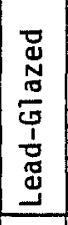 & 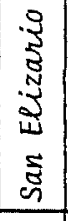 & 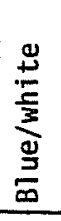 & 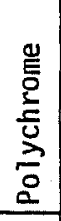 & 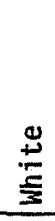 & 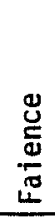 & & & & & & & & & & & \\
\hline $\begin{array}{l}27-28 \\
27-28 \\
27-28 \\
27-28 \\
27-28 \\
27-28 \\
27-28 \\
\end{array}$ & $\begin{array}{l}1-3 \\
4 \\
5 \\
6 \\
7 \\
8 \\
9 \\
\end{array}$ & $\begin{array}{l}1 \\
2 \\
4 \\
2 \\
5 \\
4 \\
\end{array}$ & $\begin{array}{l}1 \\
3 \\
1 \\
2 \\
2\end{array}$ & & & & 1 & & & & & & & $\begin{array}{r}12 \\
30 \\
48 \\
102 \\
134 \\
168 \\
346\end{array}$ & $\begin{array}{l}2 \\
2 \\
1\end{array}$ & & & 11 & \\
\hline $\begin{array}{l}29 \\
29 \\
\end{array}$ & $\begin{array}{l}4 \\
5-9 \\
\end{array}$ & 8 & 2 & & & & & & & & & & & $\begin{array}{r}12 \\
417 \\
\end{array}$ & 4 & & & $\begin{array}{r}4 \\
13\end{array}$ & \\
\hline $\begin{array}{l}31 \\
31 \\
31 \\
31 \\
31 \\
31 \\
\end{array}$ & $\begin{array}{l}1-2 \\
4 \\
5 \\
6 \\
7 \mathrm{a} \\
7 \mathrm{~b} \\
\end{array}$ & $\begin{array}{l}1 \\
3 \\
5\end{array}$ & 1 & & & & & & & & & . & & \begin{tabular}{|r|}
45 \\
32 \\
99 \\
358 \\
42 \\
236
\end{tabular} & & & & 4. & \\
\hline $\begin{array}{l}32 \\
32 \\
32 \\
32 \\
32 \\
32 \\
\end{array}$ & $\begin{array}{l}4 \\
5 \\
6 \\
7 \\
8 a \\
8 b \\
\end{array}$ & $\begin{array}{l}2 \\
3 \\
8 \\
\end{array}$ & $\pi$ & & & & & & & & & & & $\begin{array}{r}12 \\
9 \\
26 \\
570 \\
312 \\
949 \\
\end{array}$ & & & & 2 & 1 \\
\hline $\begin{array}{l}33 \\
33 \\
33 \\
33 \\
\end{array}$ & $\begin{array}{l}3 \\
4 \\
5 \\
6 \\
\end{array}$ & 6 & 5 & 1 & & & & & & & & & & $\begin{array}{r}21 \\
17 \\
12 \\
765\end{array}$ & & & & 6 & \\
\hline $\begin{array}{l}34 \\
34 \\
34 \\
34 \\
34 \\
34 \\
\end{array}$ & $\begin{array}{l}4 \\
F 3 \\
5 \\
\text { F4 } \\
6 \\
\text { F5 } \\
\end{array}$ & $\begin{array}{l}2 \\
1\end{array}$ & 1 & & & & & & 1 & & & & & $\begin{array}{r}32 \\
62 \\
734 \\
66 \\
317 \\
38\end{array}$ & 1 & & & 3 & \\
\hline $\begin{array}{l}36 \\
36 \\
36 \\
\end{array}$ & $\begin{array}{l}4 \\
5 \\
6 \\
\end{array}$ & 2 & 1 & & 1 & & 1 & & & & & & & $\begin{array}{r}44 \\
33 \\
326\end{array}$ & & & & & \\
\hline $\begin{array}{l}46 \\
46\end{array}$ & $\begin{array}{l}4 \\
5\end{array}$ & 7 & & & & & & & & & & & & 24 & & & & & \\
\hline TOTALS & & 63 & 22 & 1 & 1 & & 2 & & 2 & & & & & 6441 & 10 & & & 58 & 1 \\
\hline
\end{tabular}


TABLE 1. (continued)

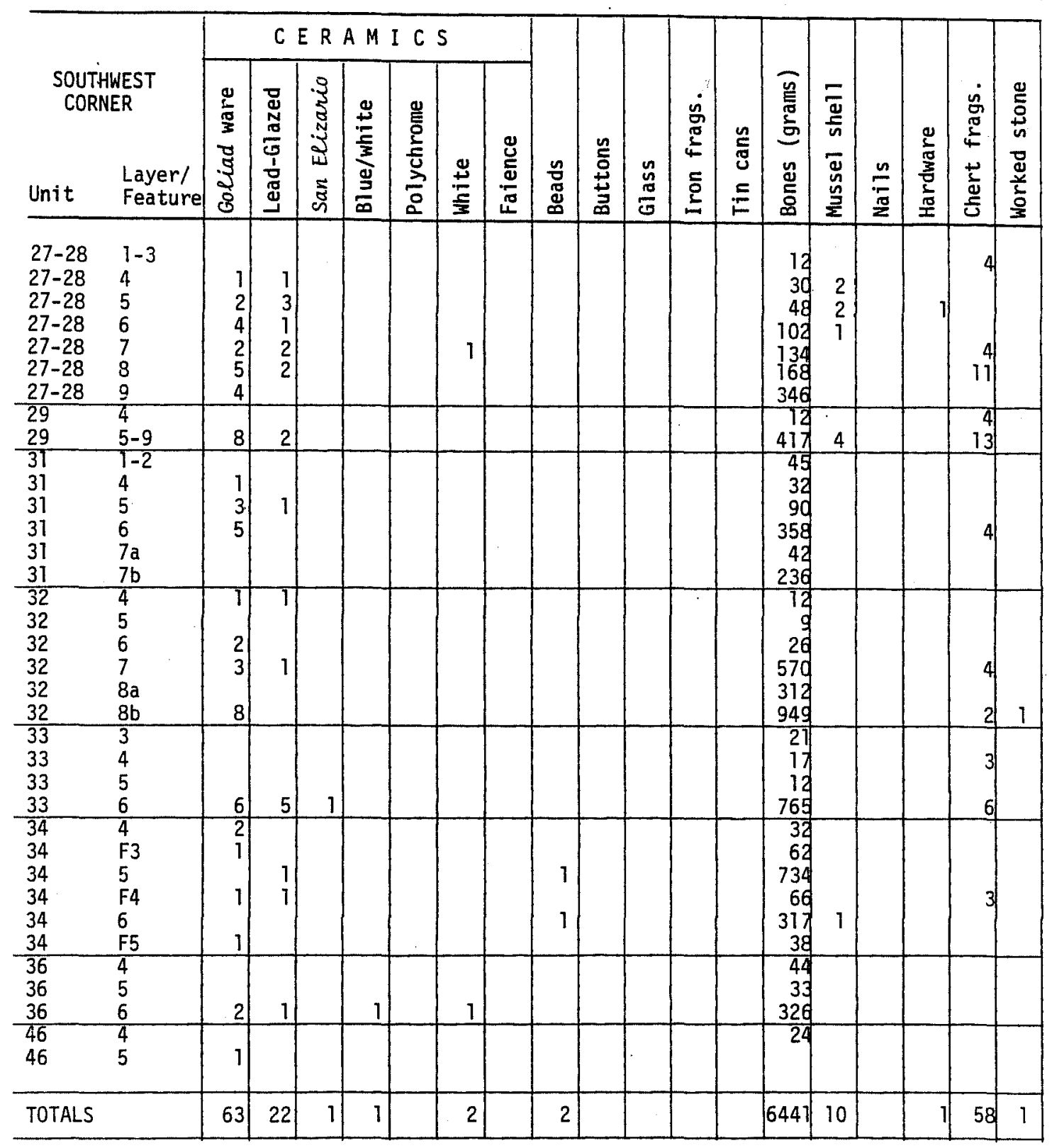


might be considered somewhat exotic as far as their frequency and general utility are concerned, this is not surprising in the rather basic, utilitarian southwest corner collection, but in the northeast corner where majolica makes up such a large proportion of the ceramics, it is unexpected.

In this year's collection, there was hardly any horse gear and no hint of arms, in contrast to the collections of previous years. Perhaps such objects were more likely to be discarded in trash pits than dropped or casually tossed aside and trampled underfoot.

The area in the southwest corner yielded primarily Goliad and lead-glazed ceramics, along with a large amount of bone and a high proportion of chert fragments. In this area, the artifacts appear to be concentrated in Stratum 5 (see Table 1), from the surface of which the postholes were dug. The quantity and concentration of artifacts and bone in this area are not nearly so intense as in Area A of last year's excavation (Ivey 1983:Fig. 2). This suggests that it was not a center of intensive occupation. However, it might have been used sporadically, perhaps for some sort of seasonal activity involving food preparation. This suggestion is based on the presence of the mano fragment, the preponderance of Goliad and lead-glazed wares, and the amount of animal bone present. The postholes could represent some sort of ramada built to provide shade in this area for the activities going on there.

The chapel area contained an unusually high proportion of majolica sherds along with some glass, a few nails, and a button. A large amount of bone, about twice the weight of that in the southwest corner excavations, added to the other artifacts, would seem to indicate occupation in the immediate vicinity. It should be stressed that the excavations in the area in front of the chapel for the most part, were not carried much below the top of the major artifact-bearing stratum (Stratum 5) and, therefore, much of the evidence for occupation during the period before 1772 probably has not been recovered. Since the assignment for this season was to test the area for the presence of burials, work was 1 imited to examination of the surface from which the chapel was constructed, since this would also be the surface from which any burials would have originated.

Distribution of the artifacts within the area suggests a concentration of activity in the immediate vicinity of the jacal structure, and between that feature and the original compound wa11. At least this is true for Stratum 4. At another time, the entire area in front of the chapel should be systematically excavated so as to be able to properly examine the sequence of events which took place there. 


\section{INTERPRETATIONS}

The most significant contributions of this season's field work to the interpretation of the structural history of Rancho de las Cabras are centered in two areas. The first of these contributions is the overlapping postholes located in Unit 34 (Features 4 and 5). These postholes were exposed in the surface of Stratum 5, a series of thin depositional 1ayers. The postholes in Stratum 5 may be related to the posthole in Unit 7 (1980) and together may form some sort of structure. A line extended from the posthole in Unit 7 through those in Unit 34 to the south wall of the compound, intersect the wall at an angle of approximately $90^{\circ}$. Whether this is significant cannot be established at present.

The overlapping nature of the postholes in Unit 34 suggests that the later posthole (Feature 4) replaced the earlier one (Feature 5). Whether this was due to the deterioration of the earlier one, or because the original structure was damaged through some calamity (i.e., fire, Indian raids, etc.,) is not clear. The absence of an associated jacal wall is equally puzzling and, at present, suggests that whatever structure may have existed in this area was without walls. The span between the postholes in Unit 34 and Unit 7 is approximately two and one-half meters. Ivey (1983) notes that the 1772 Mission Espada inventory of the compound includes ". . . an adequate corral of nailed and tied timbers, and four bull pens. ...." These facilities may have been within the compound walls, but no specific location is given in the inventory.

The diameter of the postholes could also suggest that the posts were uprights which functioned in some sort of weight bearing capacity. With the absence of any jacal trench lines, this could suggest that a ramada was located in this corner. A ramada usually consisted of four corner posts which were connected by crossmembers at the top. These crossmembers, in turn, would support some sort of materials to provide a shade cover. Such materials would include hay, brush, small poles, or any readily available material. Ramadas were often attached to the side of an enclosed structure to form a type of overhanging porch (see Fig. 11).

Further excavation of this area would be needed to expose additional structural characteristics before a more definite interpretation can be made. It is apparent that activity of some sort was occurring in this portion of the compound. Bone, Goliad ware, and lead-glazed ceramics account for the majority of the cultural materials recovered. A mano fragment was also recovered from this area. Such materials normally indicate activities associated with food processing and preparation; however, no hearths or fire pits have yet been clearly recognized in this area.

Further archaeological testing is needed in the southwest corner of the compound. Such work may enable future analyses to recognize distinct activity patterns. Ideally this entire area should be exposed in order to properly assess the available evidence.

The second area of significance revealed during this season's field work was centered in Units $30,37,42$, and 45 , which were directly in front of the south wall of the chapel (Fig. 7). Feature 1 was recognized in this area and consisted of a posthole and an associated jacal trench 1 ine located in 


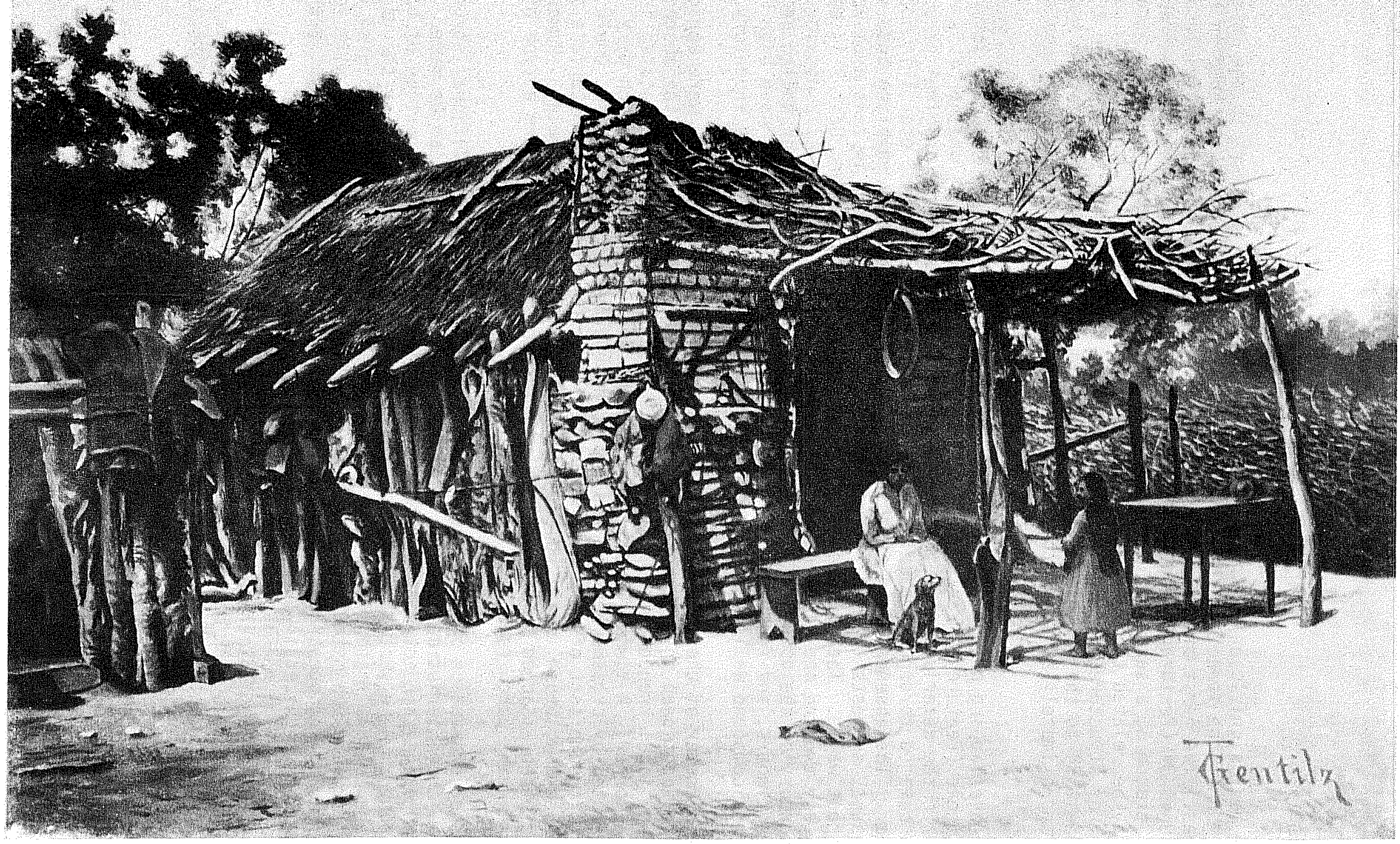

Figure 11. Jacal in San Antonio, Mid-19th Century. This painting by artist Theodore Gentilz shows the typical jacal made of upright poles and thatched roof. The structures within the compound at Rancho de las Cabras probably looked very much the same. 
the eastern portion of Unit 30, an extension of the jacal line in Unit 37, a second posthole with a jacal line in Unit 42, and a third posthole in the west wall of Unit 45. Feature 2, a larger posthole, located in the western portion of Unit 30 is probably associated with the Feature 1 structure, but the relationship is not entirely clear. The postholes and the associated jacal lines in Feature 1 indicate what was once the wall of a structure that may have been attached to, or secured by, the original east wall of the compound. The distance from the postholes to the old east wall vary from three meters (Unit 30) to $2.75 \mathrm{~m}$ (Unit 45). This structure appears to predate the construction of the chapel for a number of reasons. A layer of sandstone rubble was noted across Units 42 and 45 (see profile drawings, Fig. 9). This rubble was similar to the sandstone which was used to build the chapel. This rubble layer also overlaid the hard-packed, artifact bearing layer in these units (Stratum 4). The rubble was also noted in the posthole in Unit 45, indicating that the posthole existed prior to the chapel construction.

In spite of the badly disturbed nature of the compound adjacent to the chapel, enough undisturbed cultural materials were recovered to permit some limited observations to be made. Unlike the southwest corner units, which contained a relative abundance of Goliad ware and lead-glazed ceramics, the chapel area units, especially Units 30 and 35, contained a high percentage of majolica fragments. Goliad ware, bone, tin-glazed ceramics, and lead-glazed materials were also recovered, but the presence of majolica in such quantities presents new questions which may be answered by future research. One such question is whether such a dichotomy of ceramic types within specific locations in the compound indicates some sort of social stratification existed during all, or part, of the compound's history; or whether such evidence reflects different periods in which the compound was occupied. Further field work in association with Feature 1 is needed to properly assess the evidence acquired during this season's field work.

The implications from the faunal analysis that some sort of structure may have stood in the area in front of the chapel during the time period after the deposition of the dung layer are interesting and should be pursued further. We have not as yet been able to date this deposition. After conversation with local residents, we now believe that an intensive search for and interviews with those whose families attended church services at the chapel in the late 19th century may yield helpful information about later use of the site.

\section{CONCLUSIONS}

One of the two objectives of this season's activities was to determine the existence of burials associated with the chapel. Sufficient units were placed in the areas adjacent to the chapel in which burial activity would be the most likely, but no burials were found at Rancho de las Cabras in the eastern portion of the compound. This suggests two possibilities: that individuals who died at Rancho de las Cabras were transported elsewhere for interment, or that the occupants of the ranch maintained some sort of cemetery, yet to be located, away from the compound. It is also possible that there are burials beneath the floor of the chapel. Further archival research of materials associated with Rancho de las Cabras and Mission Espada may reveal information which could clarify this matter. 
The second objective of this season's field work was to continue testing within the compound for further structural evidence. The two areas selected for this season revealed additional data concerning the occupation of the compound and structural features associated with that occupation. Evidence of prechapel construction was obtained during this season's field work. Future efforts in this area may help in establishing the construction date of the chapel and, possibly, shed light on when the one or more major compound renovations occurred.

Additional data concerning the occupational activities of the compound occupants was accumulated during this season's work and will be of assistance in planning research designs for future archaeological investigations at Rancho de Tas Cabras.

\section{RECOMMENDATIONS}

A great deal has been accomplished over the past three years in our research into the history of Rancho de las Cabras. However, there are several important questions to which the answers are not yet clear. We suggest that these be examined in some depth before planning gets underway on the interpretation of the site to the public.

A more precise date is needed for the change in the outline of the walls and the construction of the bastions and chapel. Did this all happen at once, or was it a gradual, developmental change? Also, when in the course of events were the stone rooms built against the north wal1, and how many rooms were there?

The location of the second gate is also a question of considerable interest which should be pursued. We feel that we have narrowed down the possibilities to the point where it should be possible to locate this important feature.

The most urgent historical research which still needs to be done is in the area of local history among the residents of the area. During the celebration of a Field Mass at the site this past summer, a number of local people came forward to relate memories of having been to Rancho de las Cabras as a child or hearing relatives tell about it. We need to make a concerted effort to contact local families and interview elderly people who have important information and perhaps personal photographs of the site. Recent concerted efforts by the staff of the San Antonio Missions National Historical Park have turned up invaluable old mission photographs and more undoubtedly exist in the Floresville area.

We, therefore, suggest that work during the fourth season concentrate on testing which will answer at least some of the above questions. We would also like to suggest that a program of personal interviews with older local residents be initiated as soon as possible. 


\section{REFERENCES CITED}

Barnes, M. R. and R. V. May

1972 Mexican Majolica in Northern New Spain. Pacific Coast Archaeological Society Occasional Paper 2.

Bexar Archives (BA)

Microfilm copy in John Peace Library, The University of Texas at San Antonio.

Bexar County, Texas

Bexar County Archives ( $B C A$ )

Land Grant and Sales.

Mission Records.

Originals and microfilm in Bexar County Courthouse, San Antonio, Texas.

Bexar County Deed Records (BCDR)

Originals and microfilm in Bexar County Courthouse, San Antonio, Texas.

Bexar County Probate Court Records (BCPCR)

Originals in Bexar County Courthouse, San Antonio, Texas.

Chabot, F. C.

1937 With the Makers of San Antonio. Artes Graficas Press, San Antonio.

Cox, I. J.

1902 The Early Settlers of San Fernando. Texas Historical Association Quarterly $V: 142-161$.

Deuval1, A. F. and P. A. Rodriguez

1975 Our Family Heritage. Graphic Arts, San Antonio, Texas.

Forrestal, P. B., (Translator)

1931 The Sol is Diary of 1767. Preliminary Studies of the Texas Catholic Historical Society 1(6).

Fox, A. A.

1974 Lead Glazed Wares. In Mission Rosario Archeological Investigations 1973, by K. Gilmore:55-60. Texas Parks and Wildlife Department, Parks Division, Historic Sites and Restoration Branch, Archeological Report 14, Part 1. 
Fox, A. A., F. A. Bass, Jr., and T. R. Hester

1976 The Archaeology and History of Alamo Plaza. Center for Archaeological Research. The University of Texas at San Antonio, Archaeological Survey Report 16.

Garrett, J. K.

1939 Green Flag Over Texas. Pemberton Press, Austin, Texas.

General Land Office (GLO)

Spanish Archives. Austin, Texas.

Gerald, R. E.

1968 Spanish Presidios of the Late Eighteenth Century in Northern New Spain. Museum of New Mexico Research Records 7.

Goggin, J. M.

1964 The Spanish 01 ive Jar. Indian and Spanish Selected Writings. University of Miami Press, Coral Gables, Florida.

Habig, M. A.

1968 The Alamo Chain of Missions. A History of San Antonio's Five old Missions. Franciscan Herald Press, Chicago.

Harris, R. K. and I. M. Harris

1967 Trade Beads, Projectile Points, and Knives. In A Pilot Study of Wichita Indian Archaeology and Ethnohistory. Assembled by R. B. Bel1, E. B. Jelks, and W. W. Newcomb:129-162. Report to the National Science Foundation, Grant GS-964.

Ivey, J. E.

1983 Archaeological Testing at Rancho de las Cabras, Wilson County, Texas. Second Season. Center for Archaeological Research, The University of Texas at San Antonio, Archaeological Survey Report 121.

Ivey, J. E. and A. A. Fox

1981 Archaeological Survey and Testing at Rancho de las Cabras, Wilson County, Texas. Center for Archaeological Research, The University of Texas at San Antonio, Archaeological Survey Report 104. 
Ivey, J. E. and A. A. Fox (continued)

1983 Archaeological Investigations at Mission Concepción and Mission Parkway. Center for Archaeological Research, The University of Texas at San Antonio, Archaeological Survey Report 114 (in preparation).

San Fernando Archives (SFA)

Baptismal Records.

Birth Records.

Burial Records.

Camposanto Burial Records.

Census Records.

Marriage Records.

Catholic Chancery, San Antonio, Texas.

Schuetz, M. K.

1969 Description of the Artifacts and Ethno-History of the Coahuiltecan Indians. The History and Archeology of Mission San Juan Capistrano, San Antonio, Texas II. State Building Commission Archeological Program, Report 11.

Seifert, D. J.

1977 Archaeological Majolicas of the Rural Teotihuacan Valley, Mexico. Ph.D. dissertation, University of Iowa.

Steinbomer, D. K.

1974 Gentilz Artist of the Oed Southwest. University of Texas Press; Austin.

Tunne11, C. D. and J. R. Ambler

1967 Archeological Excavations at Presidio San Agustin de Ahumada. State Building Commission Archeological Program, Report 6.

Wilson County, Texas

Wilson County Deed Records (WCDR)

Wilson County Courthouse, Floresville, Texas.

218th Judicial District Court Records

Wilson County Courthouse, Floresville, Texas. 


\section{APPENDIX \\ PROVENIENCE OF FAUNAL MATERIAL \\ William McClure}

Fish

Channel catfish, Ictalurus punctatus

At least five individuals are represented by the bones recovered. Most of the material matches closely, but a few elements may be other species. Size is estimated.

The following elements were recovered:

parasphenoid, caudal end, $90 \mathrm{~cm}$ (Unit 44, Layer 6);

bones that interlock with preopercular and hyomandibular, $50 \mathrm{~cm}$ (two in Unit 30, Layer 4W);

fragment of a bone that interlocks with preopercular and hyomandibular (Unit 34, Layer 6);

socket for pectoral spine, $50 \mathrm{~cm}$ (Unit 44, Layer 4);

sockets for pectoral spine, $90 \mathrm{~cm}$ (two in Unit 44, Layer 6);

right mandibles, $90 \mathrm{~cm}$ (Unit 37, Layer 2; Unit 44, Layer 4);

right cleithrum, $30 \mathrm{~cm}$ (Feature 6);

preopercular (Unit 30, Layer 6);

trunk vertebra, $90 \mathrm{~cm}$ (Unit 33, Layer 6);

trunk vertebrae, $50 \mathrm{~cm}$ (Unit 30, Layer 4W; Unit 32, Layer 6; three in Unit 38-39, Layer 4; Unit 38, Layer 6; Feature 11);

caudal vertebra, $90 \mathrm{~cm}$ (Unit 27-28, Layer 5);

caudal vertebrae, $50 \mathrm{~cm}$ (Unit 33, Layer 6; Unit 31, Layer 5; Unit 32, Layer 6; Unit 38, Layer 5; Feature 11).

Freshwater drum, Aplodinotus grunniens

This bone was assigned to this genus and species as other genera are $150 \mathrm{~km}$ away at the coast:

enlarged bone between the vertebra and dorsal bones, $8 \mathrm{~cm}$ (Unit 30 , Layer 4W). 
Unidentified fish

The following elements were recovered:

trunk vertebrae (Unit 33, Layer 6; two in Feature 11; Unit 44, Layer 4; Unit 45, Layer 4);

caudal vertebrae (two in Feature 11);

miscellaneous fragments (two in Unit 27-28, Layer 5; Unit 27-28, Layer 6; two in Unit 27-28, Layer 9; two in Unit 30, Layer 4E; five in Unit 30, Layer 4W; Unit 31, Layer 5; Unit 31, Layer 6; three in Unit 35, Layer 4E; Unit 35, Layer 4W; Unit 36, Layer 6; Unit 38, Layer 3; Unit 38, Layer 5; Unit 38-39, Layer 4; two in Unit 40, Layer 3; Unit 42, Layer 2; two in Unit 43, Layer 4; Unit 43-44, Layer 5; two in Unit 44, Layer 4; two in Unit 44, Layer 6; two in Feature 6; two in Feature 11; Feature 12).

Amphibians

Toad, Bufo sp.

Identified by a radio-ulna (Feature 6 ).

\section{Reptiles}

King snake, Lampropeltis, either calligaster or getulus

Identified by a vertebra, length about $120 \mathrm{~cm}$ (Unit 27-28, Layer 5).

Rat snake, Elaphe cf. obsoleta

Identified by vertebrae, length about $150 \mathrm{~cm}$ (two in Unit 30, Layer 2; two in Unit 35, Layer 4W; Unit 35, Layer 4E; Unit 40, Layer 3; Unit 44, Layer 4).

Water turtle, Pseudemys sp.

Represented by at least five individuals, medium to large size. The following elements were recovered:

neural (Unit 31, Layer 5);

pleural fragments (Unit 27-28, Layer 6; two in Unit 29, Layer 5-9; Unit 32, Layer 8B; Unit 35, Layer 4C; Unit 41, Layer CU);

peripheral fragments (Feature 11, Unit 43-44, Layers 1-2); 
Common snapping turtle, Chelydra serpentina

Represented by a scapula (Unit 36, Layer 6).

Softshe11 turtle, Trionyx sp.

At least two individuals are represented, small to large. The elements recovered are as follows:

vertebra (Feature 11);

neural fragments (Feature 11; Unit 43, Layers 1 and 2);

plastron fragments (two in Feature 6).

Unidentified turtle

At least two individuals are represented. The elements recovered are as follows:

pleural fragments (Feature 11; three in Unit 33, Layer 6);

peripheral fragment (Unit 36, Layer 6);

nuchal fragment (Unit 40, Layer 3);

pelvis fragment (Unit 31 , Layer 6).

Birds

Turkey, Meleagris gallopavo

Represented by at least three individuals. The following elements were recovered:

dentary (Unit 31, Layer 6);

coracoid (Unit 30, Layer 4W; Unit 33, Layer 6);

humeri (Unit 44, Layer 4; Unit 44, Layer 6);

femur (Feature 11);

tibiotarsus (Unit 34, Layer 5; Feature 11);

phalanges (Unit 29, Layers 5-9; Unit 31, Layer 5; Unit 33, Layer 5). 
Chicken, Gallus domesticus

The following elements were recovered:

cervical vertebra (Unit 39, Layer 6);

scapula (Unit 30, Layer 4W);

coracoid (Unit 44, Layer 4);

1ateral process of sternum (Unit 44, Layer 4);

phalanx I of digit II of wing (Unit 37, Layer 1);

femur (Unit 29, Layers 5-9);

tibiotarsus (Unit 35, Layer 4W);

tarsometatarsus, female (Unit 30, Layer 4W).

Turkey vulture, Cathartes aura

Represented by the following elements:

atlas (Unit 33, Layer 6);

tibiotarsus (Feature 4);

tarsometatarsus (Unit 27-28, Layer 9).

Bobwhite, Colinus virginianus

Represented by a tarsometatarsus (Feature 12).

Unidentified bird, turkey size

Represented by the following elements:

vertebrae (Units 27-28, Layers 1-3; Unit 34, Layer 6);

fragments of fused vertebra (Unit 27-28, Layers 1-3; Unit 33, Layer 6;

Unit 38-39, Layer 4; Feature 6).

Mamma 1s

Opossum, Didelphis virginiana

At least two individuals are represented by the following elements:

mandible with $\mathrm{P}-4, \mathrm{M}-1, \mathrm{M}-2, \mathrm{M}-3$; old, worn (Unit 37, Layer 2);

radius (Unit 36 , Layer 6 ). 
Bat, genus unknown

One individual is represented by a bat smaller than a Seminole bat, Lasiurus seminolus. The following elements were recovered:

right and left humerus (Unit 44, Layer 4);

proximal half of ulna (Unit 44, Layer 4).

Eastern cottontai1, Sylvilagus floridanus

At least four individuals are represented by the following elements:

sku11 fragment (Unit 42, Layer 3);

right mandible with $\mathrm{P}-3, \mathrm{P}-4, \mathrm{M}-1, \mathrm{M}-2$, smal1 (Unit 27-28, Layer 7);

thoracic vertebrae (Unit 35, Layers 1-2; Unit 37, Layer 2);

sacra (Unit 35, Layers 1-2; Unit 37, Layer 2; Feature 6);

left innominates (Unit 35, Layers 1-2; Feature 7);

right innominate (Unit 35 , Layers 1-2);

left femur (Unit 37, Layer 2);

right femurs (Feature 6; Unit 38-39, Layer 4);

right tibia (Unit 42, Layer 1);

astragali (Unit 30, Layer 2; Unit 37, Layer 2);

metatarsal bones (two in Unit 37, Layer 2);

phalanges (Unit 30, Layer 4W; Unit 35, Layers 1-2; Unit 37, Layer 2; Unit 39, Layer 6).

Rock squirre1, Spermophilus variegatus

Represented by at least three individuals. The recovered elements are as follows:

atlas (Unit 31, Layer 5);

humeri (Unit 31, Layer 5; Feature 6);

innominates (Unit 30, Layer 2; Feature 11; Unit 44, Layer 6);

femurs (Unit 30, Layer 4W; Unit 36, Layer 6; Unit 35, Layer 4E). 
Pocket gopher, Geomys sp.

Represented by the following elements:

occiput (Unit 37, Layer 2);

humerus (Feature 13);

femur (Unit 37, Layer 2).

Pocket mouse, Perognathus sp.

Represented by a sku11 with right I-1, M-1, left I-1, P-4, M-1 (Unit 45, Layer 2).

White-footed mouse, Peromyscus sp.

Represented by a right mandible without teeth (Unit 37, Layer 2).

Hispid cotton rat, Sigmodon hispidus

Represented by at least 24 individuals. The elements recovered are as follows:

sku11 fragments (Unit 30, Layer 2; Unit 35, Layers 1-2; Unit 35, Layer 3; Unit 35, Layer 4E; seven in Unit 37, Layer 2; Unit 38-39, Layer 4;

Unit 42, Layer 3; three in Feature 6; Feature 8);

left mandibles ( $\operatorname{six}$ in Unit 35, Layers 1-2; six in Unit 37, Layer 2; two in Unit 35, Layer 4E; Unit 38, Layer 3; two in Unit 43, Layer 4; Feature 6);

right mandibles (Unit 27-28, Layer 8; five in Unit 35, Layers 1-2; 10 in Unit 37, Layer 2; four in Unit 35, Layer 4E; Feature 6; Feature 7);

lower incisors (four in Unit 35, Layers 1-2; Unit 35, Layer 4E; five in Unit 37, Layer 2; Feature 6);

upper incisors (Unit 30, Layer 2; four in Unit 35, Layer 4E; three in Unit 37, Layer 2);

left humeri (two in Unit 37, Layer 2; Feature 6);

right humeri (Unit 30, Layer 2; Unit 35, Layers 1-2; five in Unit 37, Layer 2);

right U7nae (Unit 37, Layer 2; Unit 35, Layer 4E);

left femurs (four in Unit 37, Layer 2; Unit 37, Layer 3; five in Unit 35, Layer 4E); 
Hispid cotton rat (continued)

right femurs (Unit 35, Layers 1-2; five in Unit 35, Layer 4E; Unit 35, Layer 4W; five in Unit 37, Layer 2; Unit 38-39, Layer 4);

left tibiae (Unit 35, Layers 1-2; Unit 35, Layer 3; five in Unit 35, Layer 4E; three in Unit 37, Layer 2; Unit 43, Layers 1-2);

right tibiae (Unit 35, Layer 3; three in Unit 35, Layer 4E; Unit 35, Layer 4W; Unit 37, Layer 1; three in Unit 37, Layer 2);

left scapulae (Unit 35, Layers 1-2; Unit 35, Layer 3; Unit 35, Layer 4W; Unit 35, Layer 4C; three in Unit 37, Layer 2);

right scapulae (two in Unit 35, Layers 1-2; Unit 35, Layer 3);

left innominates (Unit 27-28, Layer 8; two in Unit 35, Layers 1-2; two in Unit 35, Layer 3; two in Unit 35, Layer 4E; 10 in Unit 37, Layer 2;

Unit 38-39, Layer 4; Feature 8);

right innominates (Unit 35, Layers 1-2; Unit 35, Layer 3; five in Unit 35, Layer 4E; seven in Unit 37, Layer 2; Unit 43, Layers 1-2);

vertebrae (Unit 35, Layers 1-2; two in Unit 35, Layer 3; four in Unit 35, Layer 4E; nine in Unit 37, Layer 2; Unit 38-39, Layer 4; Unit 43, Layers $1-2)$.

Southern plains woodrat, Neotoma micropus

At least two individuals are represented by the following elements:

humeri (Unit 27-28, Layer 7; Feature 11);

tibia (Unit 43-44, Layer 5);

vertebra (Unit 27-28, Layer 8).

Fox(?) cf. Urocyon cineroargentatus

Represented by a lower canine tooth (Unit 33, Layer 6).

Dog, Canis familiaris

Represented by the following elements:

upper M-1, worn and smaller than a coyote (Unit 33, Layer 4);

scapula, the size of a coyote but the shape of the glenoid cavity matches the dog (Unit 43-44, Layer 5). 
Spotted skunk, Spilogale cf. putorius

Represented by a humerus (Unit 35, Layer 3).

Pig, Sus scrofa

Represented by the following elements:

left scapula (Feature 6);

cervical vertebrae (Unit 31, Layer 7B; Feature 6);

thoracic vertebra (Unit 30, Layer $3 W$ ).

Collared peccary, Tayassu tajacu

Represented by the following elements:

cervical vertebra (Unit 34, Layer 5);

thoracic vertebra (Feature 6);

right humerus (Unit 33, Layer 6).

Cow, Bos taurus

Some of the bones included here could be of bison, Bison bison. However, bison is rejected as the excavations were in a cattle ranch compound; the size of most of the material matches small to average modern range cow, and there is no ethnohistoric support for consumption of bison by the occupants. This is not a strong position, but it seems supportable. At least four, but probably more, individuals are represented. The elements recovered are as follows:

horn core fragment, tip (Unit 43, Layers 1-2);

teeth or fragments (Unit 31, Layer 5; Unit 34, Layer 6; two in Unit 35, Layer 4W; Unit 38, Layer 5; Unit 38, Layer 6; Unit 40, Layer 3; Unit 4344, Layer 6; three in Unit 44, Layer 6; two in Unit 33, Layer 6; Feature 6; 11 in Feature 11);

maxillary fragment with $M-1, M-2, M-3$ (Feature 11);

avis (Unit 43, Layers 1-2);

cervical vertebra (Unit 43-44, Layer 5);

thoracic vertebrae (Unit 27-28, Layer 9; Unit 32, Layer 8A; Unit 32, Layer 8B; two in Unit 39, Layer 6; Unit 42, Layer 2; two in Feature 7); 


\section{Cow (continued)}

thoracic vertebra fragments (Unit 32, Layer 7; Unit 32, Layer 8A; Unit 38, Layer 6; Unit 39, Layer 6; Unit 44, Layer 6, Feature 1);

Tumbar vertebrae (Unit 32, Layer 7; Unit 38, Layer 8A; two in Unit 32, Layer 8B; Unit 39, Layer 6; Unit 44, Layer 4; Unit 33, Layer 6);

1umbar vertebra fragments (Unit 27-28, Layer 9; Unit 31, Layer 6; Feature 6); sacrum fragments (two in posthole in Unit 42);

cauda 1 vertebrae (Unit 27-28, Layer 9; Unit 32, Layer 7; Unit 34, Layer 5; Unit 44, Layer 6; Unit 33, Layer 6; Feature 1; Feature 6);

vertebra fragments (Unit 27-28, Layer 9; Unit 38, Layer 6; Feature 6);

epiphyses of vertebrae (Unit 27-28, Layer 6; Unit 27-28, Layer 7; Unit 31 , Layer 6; two in Unit 32, Layer 7; four in Unit 32, Layer 8B; Unit 34, Layer 5; Unit 35, Layer 4E; Unit 35, Layer 4W; Unit 37, Layer 2; Unit 39, Layer 6; two in Unit 44, Layer 4; Unit 33, Layer 6; three in Feature 6;

Feature 8);

rib fragments (Unit 30, Layer 5E; Unit 31, Layer 6; five in Unit 32, Layer 7 ; Unit 32, Layer 8B; Unit 35, Layers 1-2; three in Unit 44, Layer 6; seven in Feature 11);

sternum fragments (Unit 34, Layer 6; two in Feature 6);

left scapula (Unit 39, Layer 6);

left humerus fragments (Unit 32, Layer 8B; Unit 30, Layer 4W);

right humerus fragments (Unit 44, Layer 4; Unit 44, Layer 6);

innominate fragments (Unit 31, Layer 7B; Unit 32, Layer 7);

left femur fragment (Unit 34, Layer 5);

right femur fragments (two in Unit 35, Layer 5);

femur heads (Unit 30, Layer 3; Unit 31, Layer 7B; Unit 32, Layer 7; Unit 34, Layer 6; Unit 44, Layer 6);

left tibia fragments (Unit 43, Layers 1-2; Unit 44, Layer 6);

right tibia fragment (Unit 33, Layer 6);

tibia fragment (Unit 38-39, Layer 5);

left metacarpal (Unit 34, Layer 6);

metacarpal fragments (Unit 33, Layer 6; Unit 38-39, Layer 5); 
Cow (continued)

left metatarsal (Feature 11);

right metatarsal (Unit 40, Layers 1-2);

metatarsal fragment (Unit 43, Layers 1-2);

metapodial condyle (Unit 30, Layer 4E; Unit 31, Layer 5; Unit 31, Layer 7B; Unit 32, Layer 7; Unit 36, Layer 6);

patellae (Unit 38, Layer 6; Feature 6);

right astragali (Unit 32, Layer 8B; Feature 8);

trapezoid magnum (Unit 32, Layer 8B);

unciforms (Unit 30, Layer 3; Unit 31, Layer 7B; Unit 32, Layer 8B; Feature 4);

pisiform (Unit 30, Layer 4W);

sesamoids (Unit 27-28, Layers 1-3; Unit 34, Layer 4; Unit 34, Layer 6; Unit 39, Layer 6);

centroquartal (Unit 35, Layer 4W);

other carpals (Unit 27-28, Layer 5; Unit 32, Layer 8B; Unit 38-39, Layer 4; three in Unit 38, Layer 6; Unit 44, Layer 4; two in Unit 33, Layer 6; Feature 1);

phalanx I (Unit 32, Layer 8B; Unit 33, Layer 6; Unit 36, Layer 6; Unit 37, Layer 2; Unit 38-39, Layer 4; Unit 38, Layer 6; Feature 11);

phalanx II (Unit 27-28, Layer 6; Unit 27-28, Layer 9; Unit 30, Layer 3W; two in Unit 32, Layer 8B; Unit 38, Layer 6; Unit 39, Layer 6; Unit 40, Layer 3; two in Unit 44, Layer 4; Feature 4; Feature 7);

phalanx III (Unit 27-28, Layer 9; Unit 31, Layer 7B; two in Unit 38-39, Layer 4; Unit 44, Layer 4);

Deer, Goat, or Sheep, Odocoileus virginianus, Capra hirus, or Ovis aries

It is difficult to separate many of the bones of these three animals. However, some bones are readily separable, and others can be assigned to specific animals with some confidence when close comparison is made with other bones of the animals in question. The bones which were identifiable are tabulated by species. Perhaps more of these could be identified through more time spent with a larger comparative collection. 
Deer, Goat, or Sheep (continued)

teeth (Unit 27-28, Layer 5; Unit 30, Layer 2; Unit 30, Layer 4E; Unit 31, Layer 7B; Unit 35, Layer 4C; Unit 35, Layer 4W; Unit 38, Layer 6; three in Unit 40, Layer 3; Unit 44, Layer 4; two in Feature 11);

tooth fragments (Unit 27-28, Layer 9; three in either Unit 30, Layer 2 or Unit 33, Layer 6; Unit 30, Layer 3; Unit 30, Layer 4E; Unit 30, Layer 4W; Unit 31, Layer 5; Unit 32, Layer 4; two in Unit 32, Layer 7; two in Unit 34, Layer 6; Unit 35, Layers 1-2; Unit 35, Layer 4E; Unit 36, Layer 6; two in Unit 38, Layer 2; two in Unit 38, Layer 3; Unit 38-39, Layer 4; two in Unit 40, Layer 3; three in Feature 6; seven in Feature 11);

maxillary fragment with tooth roots (Unit 29, Layers 5-9);

mandible fragment (Unit 39, Layer 2);

cervical vertebrae (Unit 30, Layer 2; Unit 31, Layers 1-2; Unit 38-39, Layer 4; Unit 38, Layer 6; three in Unit 40, Layer 3; Unit 43, Layers 1-2; two in Unit 33, Layer 6; Feature 1; Feature 6; Feature 8);

thoracic vertebrae (Unit 27-28, Layer 5; two in Unit 30, Layer 2; two in Unit 30, Layer 3W; Unit 30, Layer 4E; Unit 30, Layer 4W; Unit 30, Layer 5E; Unit 31, Layers 1-2; Unit 34, Layer 5; Unit 35, Layers 1-2; Unit 37, Layer 1; Unit 37, Layer 2; Unit 38, Layer 3; Unit 38-39, Layer 4; two in Unit 39, Layer 2; Unit 40, Layer 3; Unit 42, Layer 2; Unit 43-44, Layer 3; two in Feature 1; six in Feature 6; Feature 7; Feature 11);

lumbar vertebrae (Unit 27-28, Layer 7; two in Unit 29, Layers 5-9; Unit 33, Layer 6; Unit 30, Layer 3; two in Unit 30, Layer 3W; Unit 30, Layer 4; Unit 35, Layer 3; Unit 35, Layer 4E; Unit 37, Layer 1; two in Unit 38-39, Layer 4; Unit 38, Layer 5; Unit 38, Layer 6; Unit 39, Layer 2; three in Unit 43-44, Layer 3; two in Unit 44, Layer 4; two in Feature 6; two in Feature 7);

sacrum fragment (Unit 39, Layer 2);

epiphyses of vertebrae (Unit 27-28, Layer 8; two in Unit 33, Layer 6;

Unit 30, Layer 3; Unit 30, Layer 4; Unit 31, Layer 7B; Unit 32, Layer 7; Unit 35, Layers 1-2; Unit 35, Layer 3; Unit 35, Layer 4W; two in Unit 35, Layer 4E; two in Unit 36, Layer 6; two in Unit 37, Layer 2; Unit 38-39, Layer 4; Unit 38-39, Layer 5; five in Unit 38, Layer 5; Unit 39, Layer 6; Unit 40, Layer 3; Unit 43, Layer 4; eight in Unit 44, Layer 4; two in Unit 44, Layer 6; Feature 4; Feature 6; Feature 7);

rib fragments (Unit 27-28, Layer 9; two in Unit 33, Layer 6; Unit 30, Layer 3W; Unit 30, Layer 4W; Unit 32, Layer 7; two in Unit 35, Layers 12; Unit 37, Layer 1; Unit 37, Layer 2; 20 in Unit 38-39, Layer 4; two in Unit 38, Layer 6; two in Unit 39, Layer 6; Unit 40, Layer 3; Unit 44, Layer 4; Unit 46, Layer 4; Feature 1; Feature 6; Feature 7; Feature 11);

scapula fragments (Unit 31, Layer 7B; Unit 38, Layer 3; two in Unit 40, Layer 3; two in Feature 6); 
Deer, Goat, or Sheep (continued)

humerus fragments (Unit 35, Layers 1-2; Unit 43, Layers 1-2; Unit 44, Layer 4; Feature 6);

ulna fragment (Unit 36, Layer 6);

femur fragment (Unit 42, Layer 1);

tibia fragments (Unit 33, Layer 3; Unit 30, Layer 5E; Unit 38-39, Layer 4; Feature 7);

metapodial fragments (Unit 36, Layer 6; Unit 44, Layer 4);

left astragalus (Unit 42, Layer 2);

trapezoid magnum (Unit 33, Layer 6; Unit 27-28, Layer 7; two in Unit 38-39, Layer 4);

other carpals and sesamoids (Unit 27-28, Layer 6; Unit 29, Layers 5-9; Unit 33, Layer 6; Unit 30, Layer 4E; Unit 32, Layer 7; Unit 32, Layer 8B; Unit 35, Layer 3; Unit 36, Layer 6; Unit 38, Layer 2; Unit 38, Layer 3; Unit 38, Layer 5; Unit 40, Layers 1-2; three in Unit 40, Layer 3; Unit 42, Layer 2; seven in Unit 44, Layer 4; three in Feature 7; Feature 11);

phalanx I (Unit 32, Layer 7; Unit 35, Layer 3; Unit 35, Layer 4E; Unit 37, Layer 2; two in Unit 38, Layer 1; Unit 42, Layer 1; Unit 43, Layers 1-2; Unit 43-44, Layers 1-2; two in Unit 44, Layer 4; two in Feature 7; three in Feature 11);

phalanx II (Unit 27-28, Layer 1-3; Unit 27-28, Layer 6; two in Unit 30, Layer 2 or Unit 33, Layer 6; two in Unit 30, Layer 4E; Unit 31, Layer 7B; Unit 35, Layer 3; Unit 38, Layer 5; Unit 39, Layer 2; Unit 42, Layer 2; two in Unit 43, Layer 4; eight in Unit 44, Layer 4; three in Feature 6; three in Feature 7; two in Feature 11);

phalanx III (Unit 27-28, Layer 5; Unit 27-28, Layer 6; Unit 30, Layer 4E; Unit 35, Layer 4E; Unit 38, Layer 3; Unit 38, Layer 5; Unit 38, Layer 6; five in Unit 44, Layer 4; two in Feature 7; Feature 11; Feature 12);

centroquartal (Unit 40, Layer 3; Unit 44, Layer 4; Feature 6; Feature 7; Feature 12);

White-tailed Deer, Odocoileus virginianus

At least three individuals are represented.

teeth (Unit 27-28, Layer 7; two in Unit 36, Layer 6; Unit 44, Layer 6; two in Feature 11); 
White-tailed Deer (continued)

left humerus fragments (Unit 36, Layer 6; Unit 40, Layer 3);

right humerus fragment (Unit 27-28, Layer 8);

right scapula fragment (Unit 44 , Layer 6);

left radius fragments (Unit 31, Layer 6; Feature 6);

right radius fragment (Feature 5);

left femur fragment (Unit 44, Layer 6);

right tibia fragment (Unit 30, Layer 5E);

left metacarpal fragments (Unit 27-28, Layer 9; Unit 39, Layer 6);

right metacarpal fragments (Unit 42, Layer 2; Feature 11);

metacarpal fragments (Unit 31, Layer 6; Feature 11);

right metatarsal fragment (Unit 44, Layer 6);

metatarsal fragments (Unit 31, Layer 7A; Unit 39, Layer 2; Unit 44, Layer 6; Feature 11);

Goat, capra hirus

Represented by at least three individuals.

horn core fragment (Unit 27-28, Layers 1-3);

teeth (Unit 37, Layer 2; Unit 33, Layer 6);

sku11 fragment (Unit 31, Layer 7B);

left scapula (Unit 42, Layer 1);

left humerus (Unit 29, Layers 5-9);

right humerus (Unit 44, Layer 4);

left radius-ulna (Unit 38 , Layer 6);

left femur (Unit 30, Layer 4E);

left femur fragments (Unit 38-39, Layer 4; Feature 6);

right femur fragments (Unit 38-39, Layer 4; Feature 6);

left tibia (Unit 30, Layer 4E); 
Goat (continued)

left tibia fragment (Unit 32, Layer 8B; Unit 30, Layer 4E; Unit 44, Layer 4); right tibia fragment (Feature 11);

metacarpal fragment (Unit 33, Layer 6);

calcanei (Unit 33, Layer 3; Feature 6; Feature 7);

os malleolare (Unit 33, Layer 6);

Sheep, ovis aries

Sheep are represented by at least three individuals. The elements recovered are as follows:

sku11 fragments (two in Unit 38, Layer 6);

maxilla fragments (two in Unit 30, Layer 2; Feature 3; Feature 6);

mandible fragments (Unit 38, Layer 2; Unit 40, Layer 3; Unit 43-44, Layer 3);

teeth (Unit 27-28, Layer 5; Unit 43, Layers 1-2; Feature 8);

axis (Unit 30, Layer 2);

left scapulae (Unit 29, Layers 5-9; Unit 38-39, Layer 5);

right scapula (Unit 30, Layer 2);

left humerus fragments (Unit 27-28, Layer 9; Unit 43, Layers 1-2);

right humeri (Unit 30, Layer $4 E$; Unit 38 , Layer 6);

right humerus fragment (Feature 6);

radius fragments (Unit 38 , Layer 3 ; Unit 40, Layer 3);

right metacarpal fragment (Unit 43, Layers 1-2);

left metatarsal fragment (Feature 6);

right metatarsal (Unit 43-44, Layers 1-2);

right metatarsal fragment (Unit 34, Layer 5);

metatarsal fragments (Unit 42, Layer 1; Feature 6);

astragalus (Unit 39, Layer 2);

calcaneum (Unit 30, Layer 2);

os malleolare (Unit 44, Layer 4). 
Horse, Equus caballus

The horse is represented by at least two individuals. The following elements are represented:

tooth (Unit 45, Layer 1);

fibula (Unit 45, Layer 1);

navicular bones (Unit 27-28, Layer 8; Unit 43, Layers 1-2).

Unidentified mammals

Several bones of mammals were recovered that could not be assigned to any of the above categories. 

